\title{
NEW MEMBERS OF THE MEGASPORACEAE (PERTUSARIALES, LICHEN-FORMING ASCOMYCOTA): MEGASPORA IRANICA SPEC. NOVA AND OXNERIARIA GEN. NOVA
}

\author{
M. Haji Moniri ${ }^{1}$, A. B. Gromakova ${ }^{2}$, L. Lőkös ${ }^{3}$ and S. Y. KondratyuK ${ }^{* 4,5}$ \\ ${ }^{1}$ Department of Biology, Faculty of Sciences, Mashhad Branch, Islamic Azad University \\ Rahnamaie str., Postal Code: 9175687119 Mashhad, Iran; E-mail:m.h.moniri@mshdiau.ac.ir \\ ${ }^{2} V$. N. Karazin Kharkiv National University \\ Svobody Sq. 4, 61022 Kharkiv, Ukraine; E-mail: alla.gromakova@karazin.ua \\ ${ }^{3}$ Department of Botany, Hungarian Natural History Museum \\ H-1431 Budapest, Pf. 137, Hungary; E-mail: lokos.laszlo@nhmus.hu \\ ${ }^{4}$ M. H. Kholodny Institute of Botany, Tereshchenkivska str. 2, 01004 Kyiv-1, Ukraine \\ *E-mail: ksya_net@ukr.net \\ ${ }^{5}$ Korean Lichen Research Institute, Sunchon National University \\ Sunchon 540-742, Republic of Korea
}

(Received 6 March, 2017; Accepted 19 July, 2017)

The new species Megaspora iranica M. Haji Moniri et S. Y. Kondr. is described from NE Iran, illustrated and compared with closely related taxa. It is similar to the recently described $M$. rimisorediata, which is known from Eurasia (from SE Europe and Middle Asia (Armenia) to Central Asia, i.e. Iran and China), but differing in having larger thallus, smaller soredia, thicker cortical layer of thallus, thicker hymenium, narrower ascospores and thinner ascospore wall. Megaspora rimisorediata is for the first time recorded from Europe (eastern Ukraine, Kharkiv oblast). Additional data to its diagnosis is given based on extensive collections from Eurasia. The new genus Oxneriaria S. Y. Kondr. et L. Lőkös (for the former Aspicilia mashiginensis group) found to be a member of the Sagedia clade and positioning in distant position from the Aspicilia / Circinaria clade after three gene phylogeny based on nrITS, $28 \mathrm{~S}$ nrLSU and $12 \mathrm{~S}$ tSSU sequences. The members of the genus Oxneriaria mainly distributed in cold polar and high altitude localities of Eurasia and the northern hemisphere. Nine new combinations, i.e.: Oxneriaria dendroplaca (basionym: Lecanora dendroplaca H. Magn.), Oxneriaria haeyrenii (basionym: Lecanora haeyrenii H. Magn.), Oxneriaria mashiginensis (basionym: Lecanora mashiginensis Zahlbr.), Oxneriaria nikrapensis (basionym: Aspicilia nikrapensis Darb.), Oxneriaria permutata (basionym: Lecanora permutata Zahlbr.), Oxneriaria rivulicola (basionym: Lecanora rivulicola H. Magn.), Oxneriaria supertegens (basionym: Aspicilia supertegens Arnold), Oxneriaria verruculosa (basionym: Aspicilia verruculosa Kremp.), and Oxneriaria virginea (basionym: Aspicilia virginea Hue) are proposed.

Key words: Aspicilia, Iran, Kharkiv oblast, Megasporaceae, new species, Oxneriaria, Razavi Khorasan Province, three gene phylogeny, Ukraine 


\section{INTRODUCTION}

According to the current Outline of Ascomycota (Lumbsch and Huhndorf 2010) the Megasporaceae Lumbsch, Feige et K. Schmitz includes three genera, i.e.: Aspicilia A. Massal., Lobothallia (Clauzade et Cl. Roux) Hafellner and Megaspora (Clauzade et Cl. Roux) Hafellner et V. Wirth. Since 2013 one new genus Teuvoa Sohrabi et S. D. Leav. has been described (Sohrabi et al. 2013a), and four more genera (Agrestia J. W. Thomson, Chlorangium Link, Circinaria Link, and Sphaerothallia Nees ex Eversm.) were resurrected (Sohrabi et al. 2013b, Kondratyuk et al. 2015).

The genus Megaspora (Clauzade et $\mathrm{Cl}$. Roux) Hafellner et V. Wirth, the type genus of the Megasporaceae Lumbsch, Feige et K. Schmitz, seems to be one the best studied genera of this family from molecular point of view in contrast to other genera of the Megasporaceae, i.e. Aspicilia and Circinaria, where only small part of species diversity of the genera mentioned, are studied from molecular point of view or genera Agrestia, Chlorangium, and Teuvoa Sohrabi et S. D. Leav. (Kondratyuk et al. 2015), for which only the first data are hitherto available.

The recently described Megaspora rimisorediata Valadbeigi et A. Nordin, characterised by a pale ochraceous to bluish grey, cracked and sorediate, very rarely fertile thallus, is found to be rather commonly distributed in Iran (Valadbeigi et al. 2011). This species was also recently recorded from Armenia and China based on several collections (Gasparyan and Sipman 2013, Kondratyuk et al. 2016a) and here for the first time recorded from Europe.

During the taxonomic revision of sorediate Megaspora specimens from Asia and Europe a new taxon, described below as Megaspora iranica, was found.

One of the aims of this paper is to describe the new species, as well as to provide new European localities and new data on Megaspora rimisorediata based on extensive collections from Eurasia.

During combined phylogenetic analysis based on nrITS, 28S nrLSU and $12 \mathrm{StSSU}$ sequences the former Aspicilia mashiginensis group, mainly distributed in cold polar and high altitude localities of Eurasia and the northern hemisphere, found to be positioned in the Sagedia clade and in distant position from the Aspicilia / Circinaria clade. In all phylogenetic trees of the Megasporaceae the Aspicilia mashiginensis group was in somewhat distant position from Aspicilia s. str., i.e. Aspicilia cinerea branch (Nordin et al. 2007, 2010, Kondratyuk et al. 2016b). The new set of molecular data accumulated during last decade confirms that the former Aspicilia mashiginensis group (or the clade II sensu Nordin with colleagues (Nordin et al. 2007); or the Aspicilia dendroplaca - A. supertegens group sensu Nordin with colleagues (Nordin et al. 
2010) (see also Sohrabi et al. 2013b, Kondratyuk et al. 2016b, and this paper)) is positioned in the same robust monophyletic branch as the genera Aspicilia s. str. and Sagedia.

The new genus Oxneriaria for the former Aspicilia mashiginensis group is proposed in this paper, too.

\section{MATERIAL AND METHODS}

Our study and revisions are based on numerous specimens from the private herbarium of Haji Moniri (Iran), on collections deposited in BP, CWU, KW-L, KoLRI and TARI, as well as on some specimens from another herbaria included in a comparative study (see also Kondratyuk et al. 2016b).

Procedures of extracting, sequencing, and phylogenetic analysis are described in our previous papers (Kondratyuk et al. 2013, 2014a, b, c, 2015, 2016b). Specimens included in the phylogenetic analysis based on ITS nrDNA sequences as well as in the combined phylogenetic analysis based on ITS nrD$\mathrm{NA}, \mathrm{nrLSU}$ and $\mathrm{mtSSU}$ sequences are listed with GenBank accession numbers in the Appendix.

\section{RESULTS}

Megaspora iranica M. Haji Moniri et S. Y. Kondr., spec. nova (Figs 1-2)

MycoBank nr.: MB 822415.

It is similar to M. rimisorediata, but differs in having larger thallus, smaller soredia, thicker cortical layer of thallus, thicker hymenium, narrower ascospores and thinner ascospore walls.

Type: Iran: Razavi Khorasan Province, $15 \mathrm{~km}$ route of Dargaz to Quchan, Nokhandan, Tagan village, on bark of Morus alba L. Lat.: 37 31' N; Long.: $59^{\circ} 10^{\prime}$ E; Alt.: $900 \mathrm{~m}$ a.s.l. Coll.: Haji Moniri, M. [sine num.], 13.12.2013 (holotype: TARI; isotypes: KW-L, voucher for DNA SK D67, and BP, voucher for DNA SK D69).

Thallus to 5-10 cm across, or may form larger aggregations, crustose, whitish grey to light grey, with distinctly cracked upper surface, where cracks similarly to Megaspora rimisorediata often forming a dense net over the thallus, and usually darker, well contrasting with soredia. Thalline areoles to 10-25 $\mathrm{mm}$ long and $0.3-0.8 \mathrm{~mm}$ wide, often elongated portion perpendicularly elongated to twigs; cracks $0.2-0.4(-0.5) \mathrm{mm}$ wide. Thallus in section to $0.2-0.3 \mathrm{~mm}$ thick; cortical layer of thallus very varying in thickness, from 10-25 $\mu \mathrm{m}$ thick, 

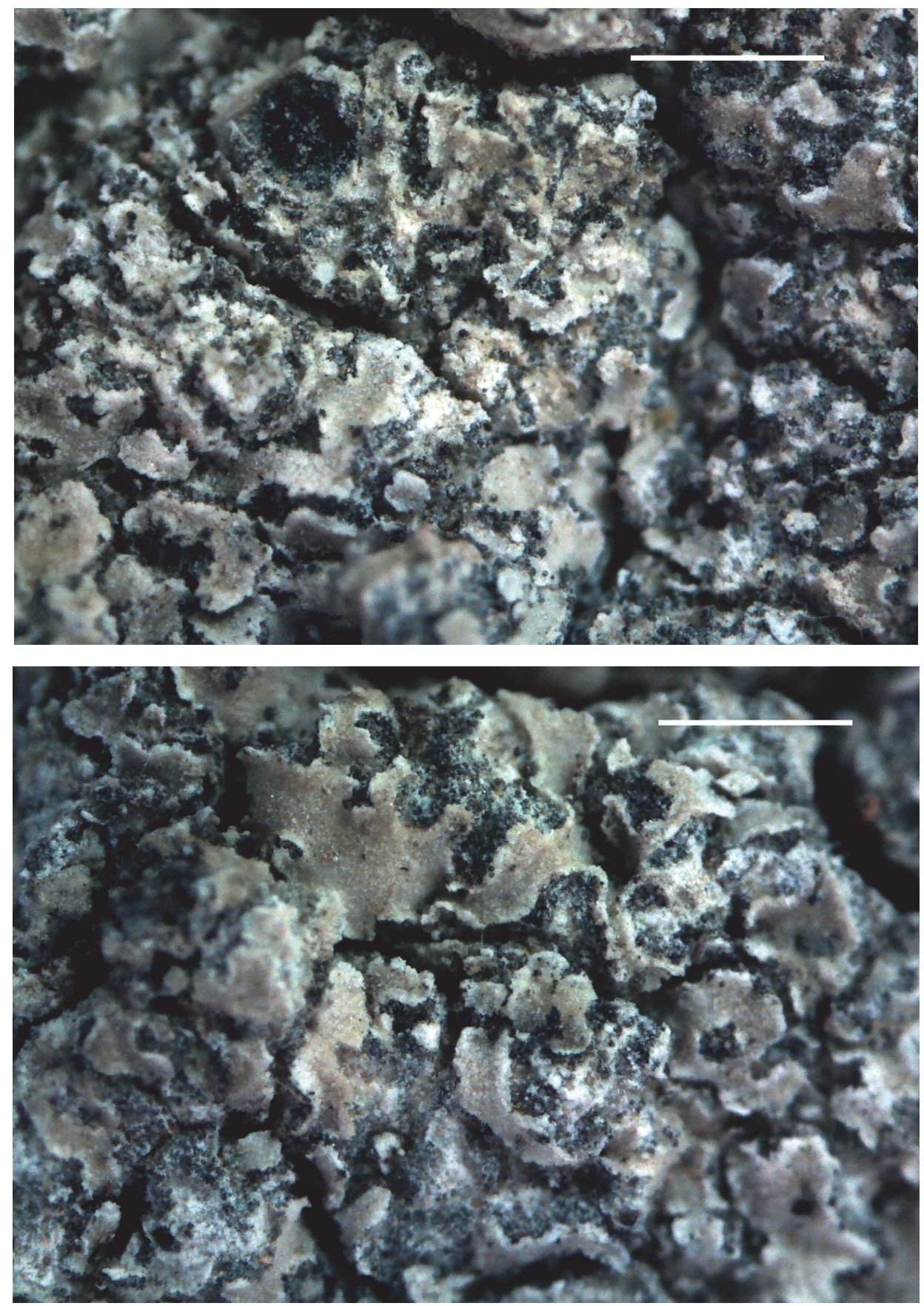

Fig. 1. Megaspora iranica (KW-L, isotype), general habit. Scale $1 \mathrm{~mm}$ (photo: S. Kondratyuk) 
with epinecral layer to $10 \mu \mathrm{m}$ thick to $(37.5-) 50-75(-100)[-175] \mu \mathrm{m}$ thick, with upper portion to $25-30(-75) \mu \mathrm{m}$ thick with numerous amount of crystals, palisade paraplectenchymatous, cell lumina rounded, 10-15 $\mu \mathrm{m}$ diam./across (almost as Massjukiella type of cortical layer in the member of the Teloschistaceae, see Fedorenko et al. 2012); algal layer 50-100 $\mu \mathrm{m}$ thick, more or less continuous, algal cells 20-25 $\mu \mathrm{m}$ diam., medulla 100-200 $\mu \mathrm{m}$ thick, more or less greyish owing to crystals; cracks/soralia to $0.2-0.4(-0.5) \mathrm{mm}$ wide. Soredia (30-)37.5-50 $\mu \mathrm{m}$ diam., with somewhat greyish outer layer owing to the numerous crystals.

Apothecia 0.8-1.3 mm diam., 0.35-0.4 mm thick in section, zeorine; true exciple (70-)90-110(-120) $\mu \mathrm{m}$ thick in the uppermost lateral portion, with 20$30 \mu \mathrm{m}$ thick uppermost blackish-greenish layer, uneven surface and groups/ aggregations of dust particles (crystals), with 20-25 $\mu \mathrm{m}$ thick necrotic layer; to $30-45(-70) \mu \mathrm{m}$ thick in lower lateral portions, hyaline, both of "textura intricata", and to 20-35 $\mu \mathrm{m}$ thick in basal portion, paraplectenchymatous with cell lumina to $4 \mu \mathrm{m}$ diam./across; hymenium to $250 \mu \mathrm{m}$ high, with oil droplets to 7-10 $\mu \mathrm{m}$ diam./across or with irregular oil aggregations; epihymenium to 60-70 $\mu \mathrm{m}$ thick dull greenish brown, epipsamma to 15-20 $\mu \mathrm{m}$ thick; paraphy-
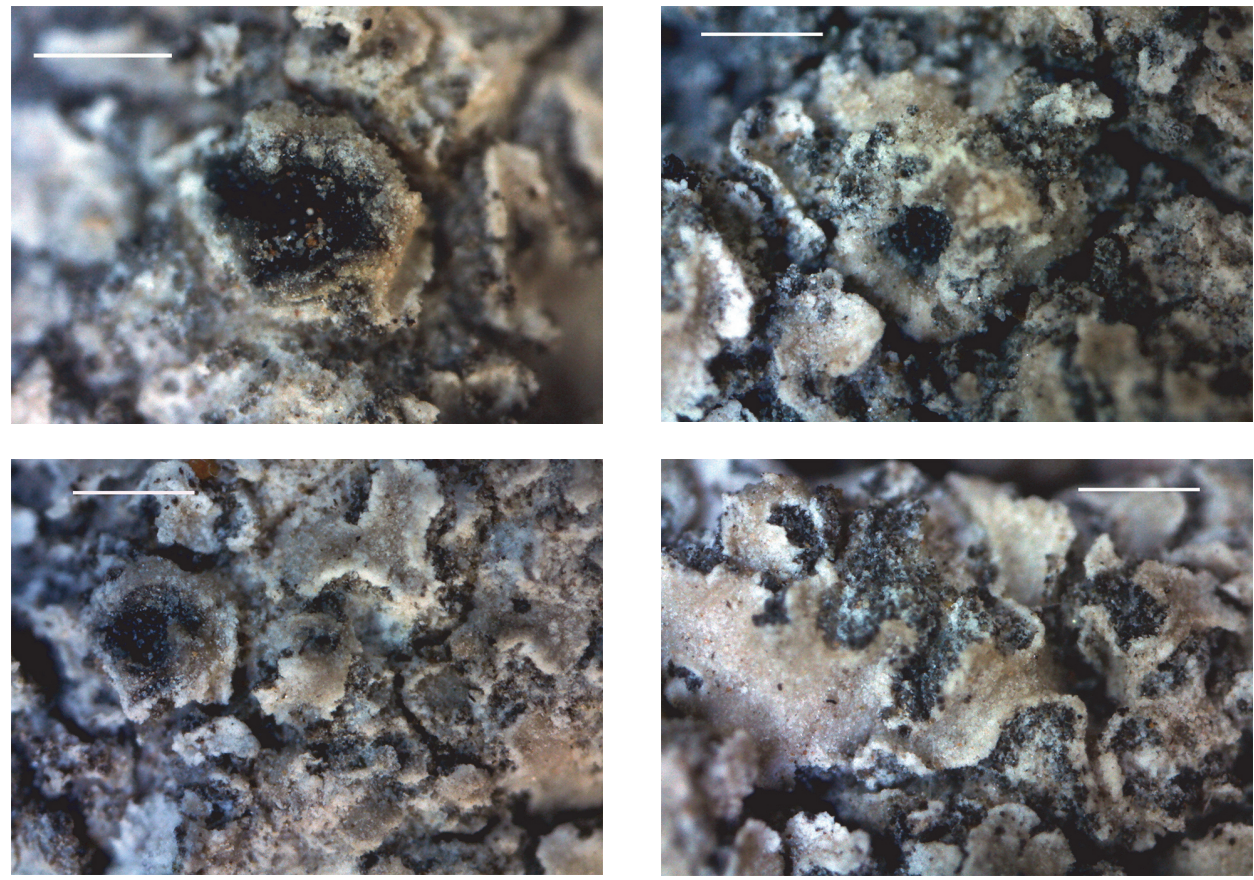

Fig. 2. Megaspora iranica (KW-L, isotype), enlarged portions with apothecia and with soralia. Scale $0.5 \mathrm{~mm}$ (photo: S. Kondratyuk) 
ses to 2.5-3(-5) $\mu \mathrm{m}$ diam.; subhymenium to 70-100 $\mu \mathrm{m}$ thick; asci 4-8-spored, ca $190 \times 40 \mu \mathrm{m}$; ascospores ovoid to widely ellipsoid, with oil droplets of 16 $\mu \mathrm{m}$ diam., $(25-) 32-37(-40) \times(16-) 17-21(-23) \mu \mathrm{m}$, at overmature becoming compressed or distorted and slightly greenish or greyish, ascospore wall to 1-1.5 $\mu \mathrm{m}$ thick.

Chemistry: Section of apothecium K+ brown, intensifying green or olive, $\mathrm{N}+$ greenish (brownish olive portions becoming intense green).

Ecology: On bark of deciduous trees (Morus alba and Acer monspessulanum).

Distribution: So far known from scattered localities in NE Iran, central Asia.

Etymology: Species epithet refers to the country of type locality, i.e.: Iran, Central Asia.

Taxonomic notes: Megaspora iranica is similar to M. rimisorediata, known from scattered localities in Eurasia (Armenia, China, Iran and Ukraine), but differs in having larger thallus (5-10 cm vs. to $4 \mathrm{~cm}$ across), in having smaller soredia ((30-)37.5-50 $\mu \mathrm{m}$ diam. vs. 50-70 $\mu \mathrm{m}$ diam./across), in having thicker cortical layer of thallus (50-75(-100) $\mu \mathrm{m}$ vs. $30 \mu \mathrm{m}$ thick), in having larger cells in cortical layer (cell lumina to 10-15 $\mu \mathrm{m}$ vs. ca 5-9 $\mu \mathrm{m}$ diam./across), in having thicker hymenium (to $250 \mu \mathrm{m}$ vs. to $150 \mu \mathrm{m}$ high), and in having distinctly narrower ascospores (32-37 × (16-)17-21(-23) vs. 35.3-38.8-42.2 × (21.5-)22.924.9-26.9(-28.3) $\mu \mathrm{m}$ after Valadbeigi et al. (2011), and (30-)35-48(-53)[-70] $\times$ (16-)21-32(-35) $\mu \mathrm{m}$ from our data see below), as well as in having narrower ascospore walls.

Note: Our measurements of fertile specimens from China, Iran (see Kondratyuk et al. 2016a) and Ukraine show that other characters (thallus, cortical layer, hymenium, etc.) of Megaspora rimisorediata have wider range of variation than it was mentioned in original description (Valadbeigi et al. 2011) (see also below), but width of ascospores and thickness of ascospore wall are more or less stable characters.

Megaspora iranica is also similar to M. cretacea Gasparayan, Zakeri et Aptroot recently described from bark of Juniperus from Armenia (Zakeri et al. 2016), but differs in having larger not lobate thallus (5-10 cm vs. to 5 $\mathrm{cm}$ across), in having smaller soredia ((30-)37.5-50 $\mu \mathrm{m}$ diam. vs. ca $0.1 \mathrm{~mm}$ diam.), in having thicker hymenium (to $250 \mu \mathrm{m}$ vs. ca $150 \mu \mathrm{m}$ high), in having 4-8-spored asci (vs. only 4-spored), and in having longer ascospores (32-37 × $(16-) 17-21(-23)$ vs. $27-31 \times 18-21 \mu \mathrm{m}$ ), as well as in different substrate (bark of deciduous trees vs. bark of Juniperus).

Voucher specimens SK D67 and SK D69 were included into molecular phylogenetic study, and according to their ITS sequences these specimens belong to the Megaspora branch of the phylogenetic tree of the Megasporaceae, where $M$. iranica together with $M$. cretacea form sister, but separate from both M. rimisorediata and M. verrucosa subbranch (Fig. 3). 


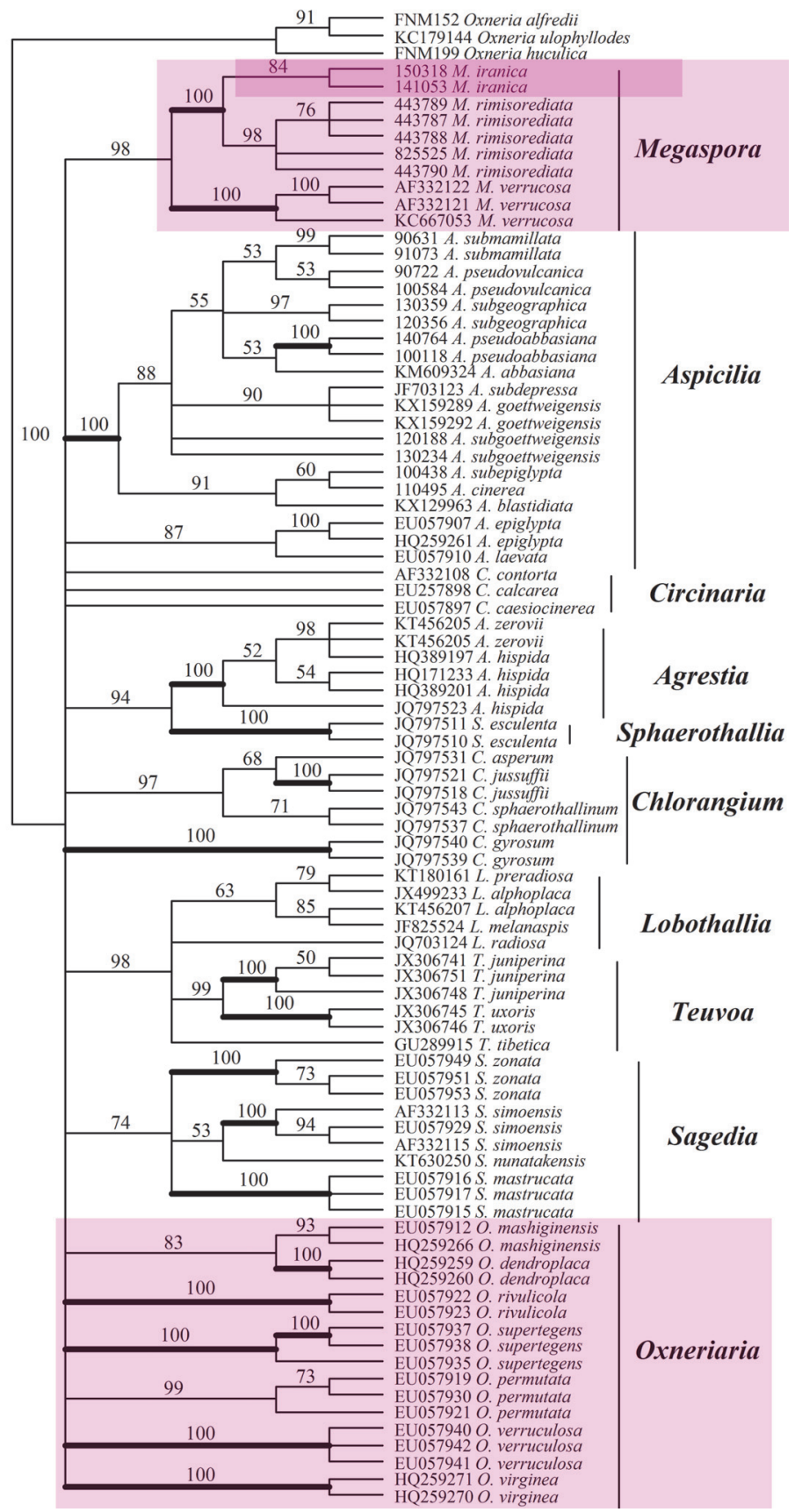

Fig. 3. Phylogenetic tree of the members of the Megasporaceae based on ITS nrDNA sequences 
Other specimens examined: Iran: Razavi Khorasan Province, $34 \mathrm{~km}$ SW of Dargaz, Cherlagh Valley, on bark of Acer monspessulanum L. Lat.: $37^{\circ} 28^{\prime} \mathrm{N}$; Long.: $58^{\circ} 50^{\prime}$ E; Alt.: 1,070 m a.s.l. Coll.: Haji Moniri, M. and Alizadeh, Z. [sine num.], 28.08.2013 (herb. Haji Moniri); Razavi Khorasan Province, $25 \mathrm{~km}$ SW of Mashhad, Jaghargh, on bark of Morus alba L. (coordinates not mentioned). Alt.: 1,200 m a.s.1. Coll.: Haji Morini, M. (2465), 15.09.2010 (herb. Haji Moniri).

\section{Megaspora rimisorediata Valadbeigi et A. Nordin}

(Figs 4-6)

As far from our study data on some characters of Megaspora rimisorediata are rather wider than those of original description of Valadbeigi et al. (2011), we provide description of this taxon based on our revision of Iranian, Chinese and Ukrainian specimens.

Thallus to $3-5 \mathrm{~cm}$ across (but sometimes thalli to $10-12 \mathrm{~cm}$ across were observed). Thalline areoles to $10-25 \mathrm{~mm}$ long and $0.3-0.8 \mathrm{~mm}$ wide, often elongated portion perpendicularly elongated to twigs; cracks $0.2-0.4(-0.5)$ $\mathrm{mm}$ wide. Thallus in section to $0.35-0.5(-0.8) \mathrm{mm}$ thick or sometimes more; cortical layer to 50-100 $\mu \mathrm{m}$ thick, developed in places, cell lumina to 12.5-15(20) $\mu \mathrm{m}$ long/across, leptodermatous paraplectenchymatous, and additionally with $50 \mu \mathrm{m}$ thick layer of crystals. Soralia somewhat elongated to $40-50 \mu \mathrm{m}$ wide and $60-80 \mu \mathrm{m}$ long or (40-)50-80 $\mu \mathrm{m}$ across. Soredia (30-)37-50(-60) $\mu \mathrm{m}$ diam. if regularly rounded, or somewhat elongate, consoredia/conblastidia type, to $50-75(-87) \mu \mathrm{m}$ long or $60-75 \times 45 \mu \mathrm{m}$, i.e.: consisting of 2 or more soredia/blastidia; sometimes very rare to almost absent or almost indistinct because of greyish-brownish to whitish- or transparent greyish colour, concolorous (in Iranian specimens, while Ukrainian material was with darker soredia).

Apothecia to $0.8-1 \mathrm{~mm}$ diam. and to $0.45-0.5 \mathrm{~mm}$ in section, somewhat seem to be smaller because being immersed into thallus (disc below of level of thallus); lecanorine with highly uplifted to $0.3 \mathrm{~mm}$ wide thalline margin, often cracked and soredious; disc to $0.3 \mathrm{~mm}$ diam., deeply concave; in section lecanorine or zeorine, thalline exciple to $100 \mu \mathrm{m}$ thick, cortical layer to (20-)30-40 $\mu \mathrm{m}$ thick, outer layer brownish or completely covered by crystals, paraplectenchymatous, cell lumina to 7-10 $\mu \mathrm{m}$ across; algal cells to $12-18 \mu \mathrm{m}$ diam.; true exciple to $50-80(-90) \mu \mathrm{m}$ thick in the uppermost lateral portion with brownish-greenish outermost layer, to $50 \mu \mathrm{m}$ thick in the lower lateral portion and to 15-20 $\mu \mathrm{m}$ thick in basal portion; hymenium to 180-230(-250) $\mu \mathrm{m}$ high with oil droplets to 8-9 $\mu \mathrm{m}$ diam.; uppermost cells of paraphyses to $7 \mu \mathrm{m}$ diam., with brown greenish or greenish-greyish to greenish-blackish uppermost portion; subhymenium to $50-60 \mu \mathrm{m}$ thick, with oil droplets to 5-6 
(-7) $\mu \mathrm{m}$ diam.; asci 6(?)-8-spored, (140-)160-170 × 32-45 $\mu \mathrm{m}$, with very thick wall to $10 \mu \mathrm{m}$ thick; ascospores regularly ovoid (one end slightly narrower) to widely ovoid or ellipsoid, (29-)35-48(-53)[-70] × (16-)21-32(-35) $\mu \mathrm{m}$ (more of 70 measurements), ascospore wall to (1-)2-3 $\mu \mathrm{m}$ thick.

Note: Our data differs from original description in having much wide variation of thalline cracks, height of hymenium, length of ascospores, and colour of soredia.

Ecology: In Ukrainian localities listed below Megaspora rimisorediata was found on bark of Artemisia salsoloides Willd., where it was often associated with M. verrucosa (Ach.) Hafellner et V. Wirth, a species, which also was recorded from soil and plant debris. Among terricolous lichens Enchylium tenax (Sw.) Gray, furthermore Megaspora verrucosa (Ach.) Hafellner et V. Wirth, Scytinium schraderi (Ach.) Otálora, P. M. Jørg. et Wedin, Endocarpon pusillum Hedw., Catapyrenium squamulosum (Ach.) Breuss and Involucropyrenium sp. were also recorded in localities mentioned.

In the first Ukrainian locality cited below (with alt.: $126 \mathrm{~m}$ a.s.l., Fig. 7) Megaspora rimisorediata was collected on rather steep slope $\left(\right.$ to $60^{\circ}$ ) of the chalk outcrops. Soil is represented by fine crushed stone with thick chalk crust. Total plant cover is about 20\%, with Artemisia salsoloides and Hyssopus cretaceus Dubjan., as dominant taxa, as well as associated plants Androsace kosopoljanskii Ovcz., Asperula cynanchica L., Cephalaria uralensis (Murray) Roem. et Schult.,
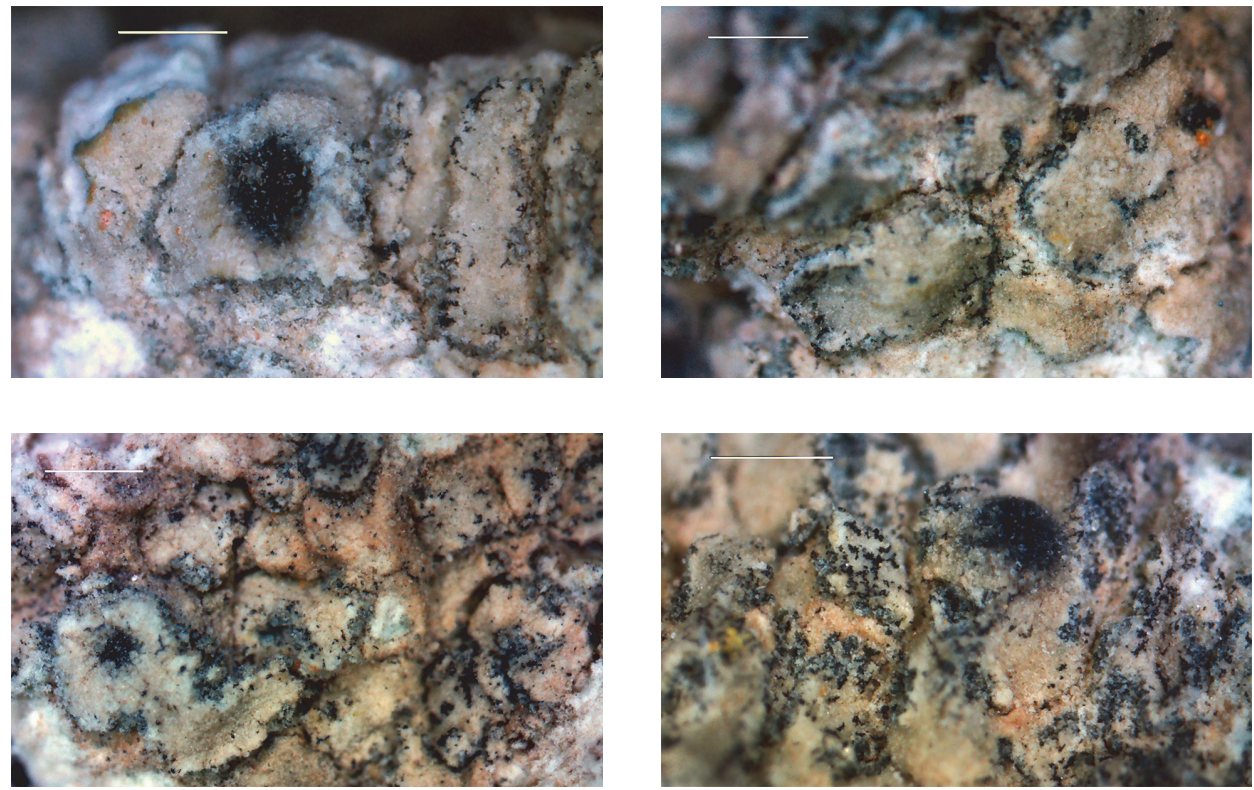

Fig. 4. Megaspora rimisorediata (Iran, Haji Moniri M. and Alizadeh Z., KW-L), enlarged portions with apothecia and soralia. Scale $0.5 \mathrm{~mm}$ (photo: S. Kondratyuk) 
Gypsophila oligosperma A. Krasnova, Pimpinella titanophila Woronow, Schivereckia mutabilis (M. Alexeenko) M. Alexeenko, Scutellaria creticola Juz., Scrophularia cretacea Fisch. ex Spreng., Silene supina M. Bieb., S. cretacea Fisch. ex Spreng., and Thymus calcareus Klokov et Des.-Shost.

In the second Ukrainian locality cited below (with alt.: $100 \mathrm{~m}$ a.s.l., Fig. 8) Megaspora rimisorediata was collected on gentle slope $\left(\right.$ about $\left.30^{\circ}\right)$ of the chalk outcrops, where total plant cover was also about 15-20\%, with Artemisia salsoloides and Thymus calcareus, as dominant taxa. Rarely, as associated taxa the following plants were recorded: Asperula cynanchica, Bupleurum falcatum L., Hyssopus cretaceus, Linaria cretacea Fisch. ex Spreng., Linum hirsutum L., Odontites luteus (L.) Clairv., Pimpinella titanophila, Scrophularia cretacea, Teucrium polium L., Vincetoxicum hirundinaria Medik.

Distribution: So far this species is known from scattered localities in Eurasia, from SE Europe (Ukraine) to Asia (Armenia, China, Iran). Some more similar specimens from Kazakhstan (Khodosovtsev, pers. comm.) are still waiting for taxonomic revision).

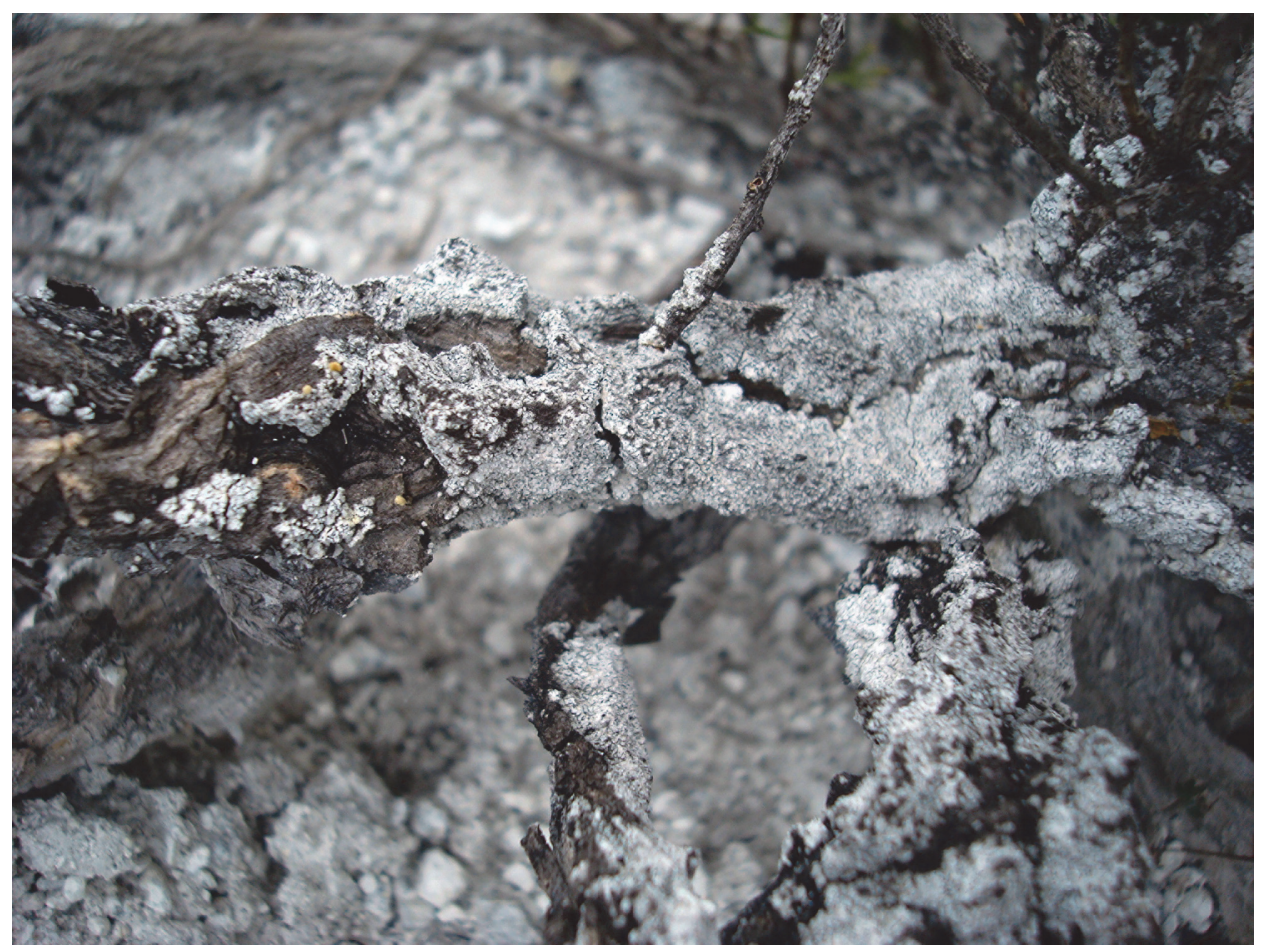

Fig. 5. Megaspora rimisorediata on bark of Artemisia salsoloides Willd. in field conditions (photo: A. Gromakova) 
Taxonomic notes: In comparison with original description thallus of Megaspora rimisorediata after our observation can be to 10-12 cm across (vs. up to $4 \mathrm{~cm}$ diam.), cortical layer of thallus may vary to $50-100 \mu \mathrm{m}$ thick (vs. ca 30 $\mu \mathrm{m}$ thick), with cell lumina to 12.5-15(-20) $\mu \mathrm{m}$ long / across (vs. cells ca 5-9 $\mu \mathrm{m}$ diam.), soredia can be from rounded to 37-50(-60) $\mu \mathrm{m}$ diam., and elongate (of consoredia type) to 50-75(-85) $\mu \mathrm{m}$ long or 60-75 $\times 45 \mu \mathrm{m}$ (vs. soredia 50-70 $\mu \mathrm{m}$ diam.), and soredia varying from greyish-brownish to whitish- or transparent greyish colour (vs. soredia blue-green). According to our data hymenium is also higher $(180-230(-250) \mu \mathrm{m}$ vs. to $150 \mu \mathrm{m}$ high), and range of ascospore measurements is wider, too $((29-) 35-48(-53) \times(16-) 21-32(-35) \mu \mathrm{m}$ $(\mathrm{n}=70)$ vs. $(33-) 35-42(-45) \times(21.5-) 23-27(-28.3) \mu \mathrm{m}(\mathrm{n}=20))$.

Thus Megaspora rimisorediata is characterised by much wider range of variation of measurements of thallus, anatomical elements of thallus, colour of soredia and may still include several taxa. The further revision of this complex based on extensive collections from other Eurasian regions including molecular phylogeny data is very desirable.

Within our study it is for the first time shown that the Megaspora verrucosa complex includes two or three separate (may be cryptic) species distinctly differing in their ITS sequences.
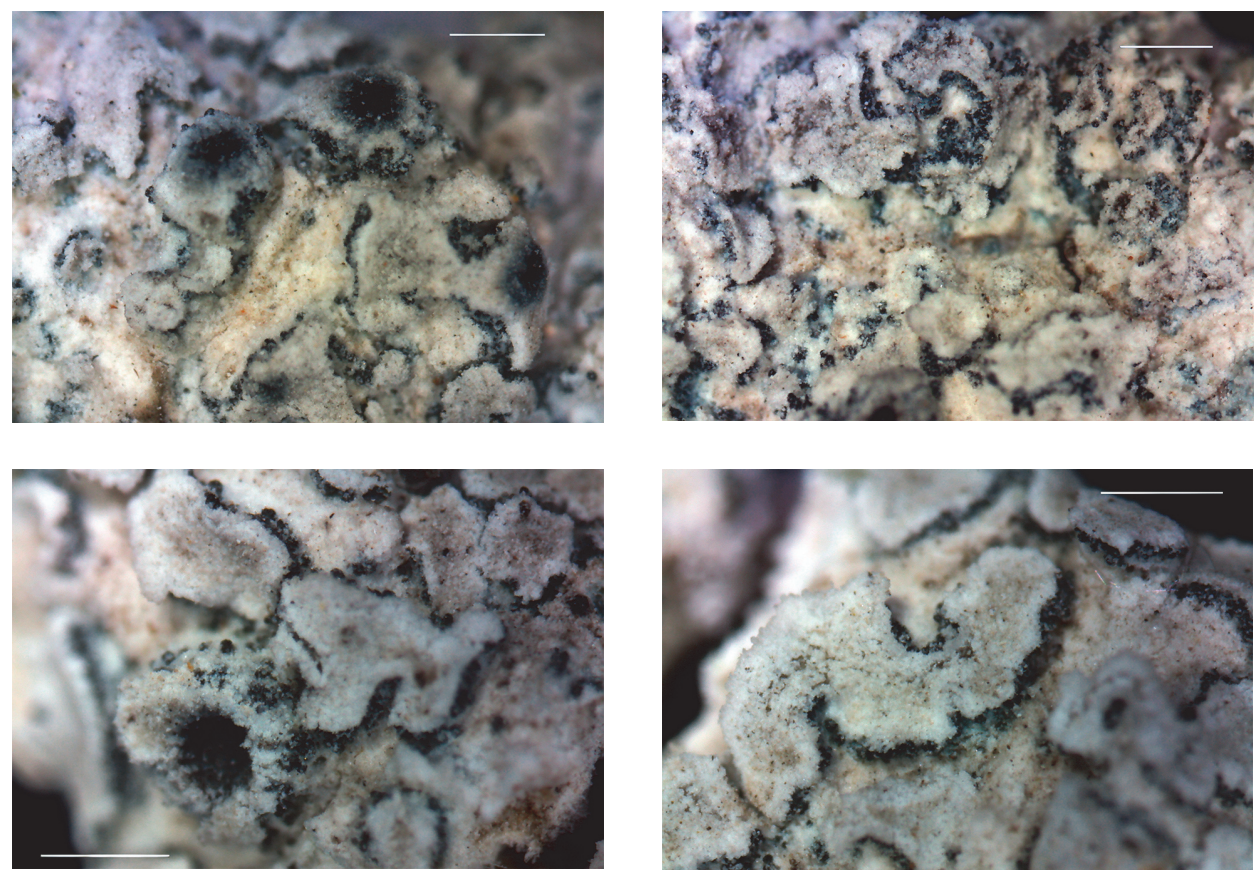

Fig. 6. Megaspora rimisorediata (Ukraine, Gromakova, A. B., 28.05.2012, KW-L), enlarged portions with apothecia and soralia. Scale $0.5 \mathrm{~mm}$ (photo: $\mathrm{S}$. Kondratyuk) 

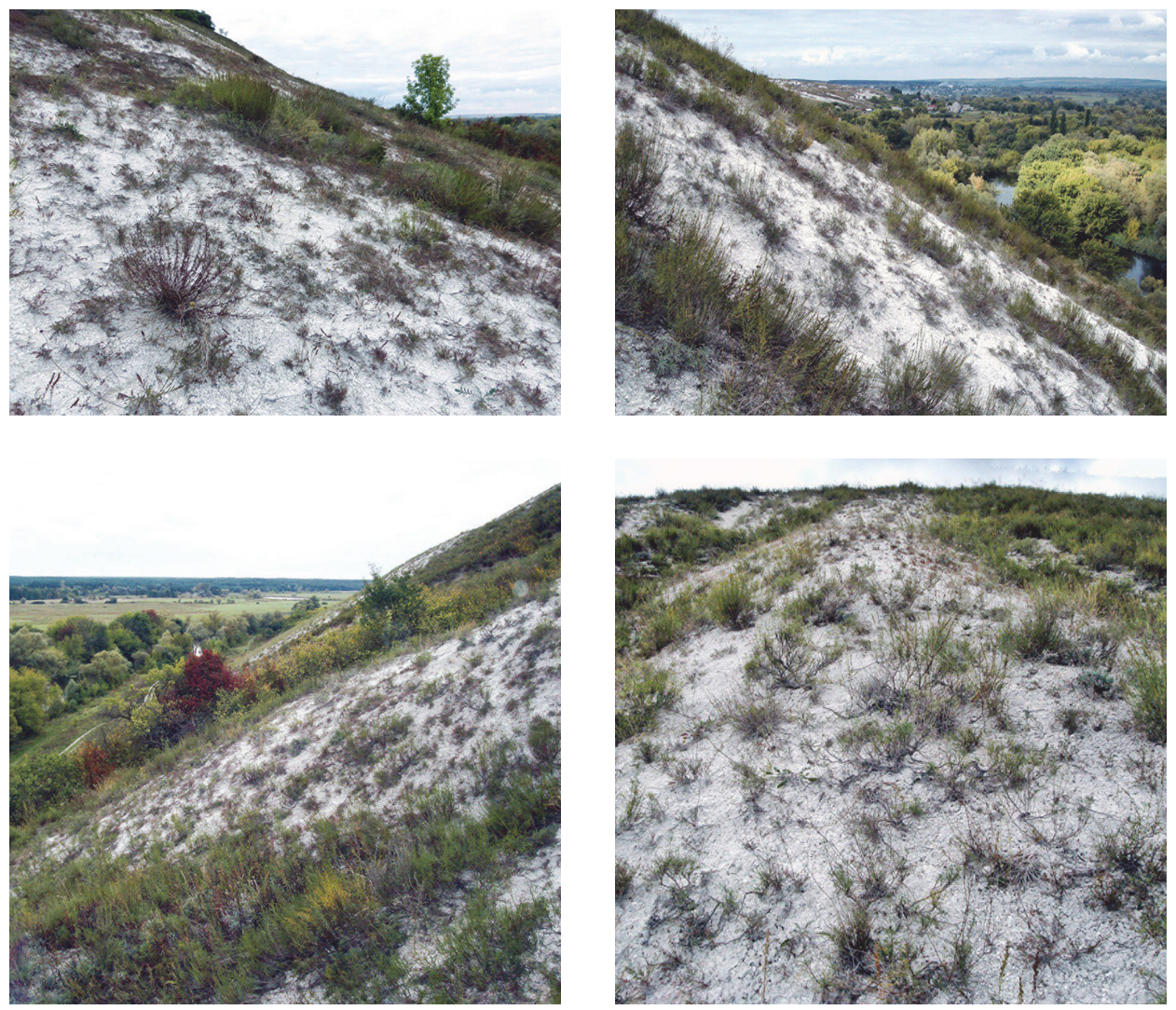

Fig. 7. General view of the first Ukrainian locality of Megaspora rimisorediata in steppes with chalk outcrops (with alt.: 126 m a.s.l.) (photo: A. Gromakova)
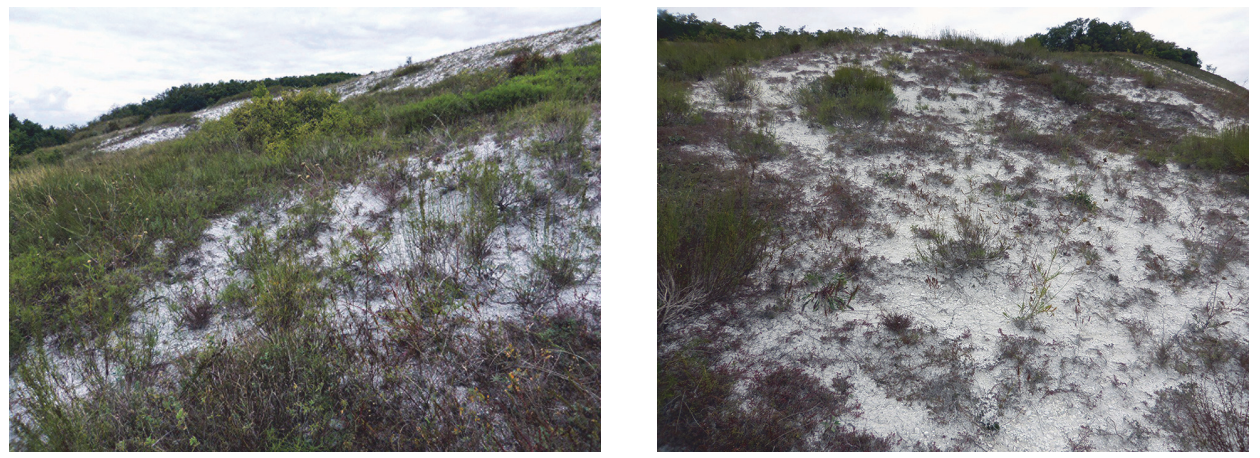

Fig. 8. General view of the second Ukrainian locality of Megaspora rimisorediata in steppes with chalk outcrops (with alt.: 100 m a.s.l.) (photo: A. Gromakova) 
Special revision of molecular data on the genus Megaspora (Megasporaceae) shows that data submitted by Zhao (unpublished, in 2017) as 'Megaspora sp.' [GenBank numbers KU535654-KU535656] belong to still unidentified Aspicilia (or Circinaria) species.

Other specimens of Megaspora rimisorediata examined: Iran: Razavi Khorasan Province, $15 \mathrm{~km}$ route of Dargaz to Quchan, Nokhandan, on bark of Morus nigra L. Lat.: $37^{\circ} 30^{\prime}$ N; Long.: 58 59’ E; Alt.: $610 \mathrm{~m}$ a.s.l. Coll.: Haji Moniri, M. and Alizadeh, Z. [sine num.], 28.08.2013 (herb. Haji Moniri, KW-L). - Ukraine: Kharkiv oblast, Dvorichansky district, in the vicinity of Dvorichna settlement, Kreidyany protected territory (= zakaznyk), on bark of Artemisia salsoloides Willd., growing on chalk outcrops. Lat.: $49^{\circ} 49^{\prime} 39.5^{\prime \prime} \mathrm{N}$; Long.: $37^{\circ}$ 40' 33.8" E; Alt.: ca 126 m a.s.l. Coll.: Gromakova, A. B. [sine num.], 28.05.2012 (CWU, KWL, see Fig. 7); the same locality, on bark of $A$. salsoloides. Lat.: $49^{\circ} 49^{\prime} 19.9^{\prime \prime} \mathrm{N}$; Long.: $37^{\circ} 40^{\prime}$ 31.7" E; Alt.: ca 100 m a.s.l. Coll.: Gromakova, A. B. [sine num.], 18.09.2016 (CWU, see Fig. 8).

\section{Oxneriaria S. Y. Kondr. et L. Lőkös, gen. nova}

MycoBank nr.: MB 822416.

Similar to the genus Aspicilia, but differs in having mostly radiating thallus with wrinkled or lobate peripheral zone, in having mainly smaller ascospores, in having substictic acid, and in having mainly polar and highly alpine distribution as well as in positioning in separate branch of the phylogenetic tree of the Megasporaceae.

Type species: Oxneriaria mashiginensis (Zahlbr.) S. Y. Kondr. et L. Lőkös.

Thallus crustose, from evenly areolate throughout to mostly more or less radiating wrinkled especially in peripheral zone or radiating lobate, sometimes distinctly zoned; areoles sometimes aggregated in branch-like or treelike formations especially in peripheral part, with soredia or isidia or without. Hypothallus dark to black, rarely white or absent. Cortical layer and algal zone more or less well developed, attached to the substrate by hyphae of medulla.

Apothecia aspicilioid or lecanorine, immersed at first, later sometimes sessile, usually numerous especially in the centre of thallus; disc mostly concave or plane, sometimes with pruina; true exciple mostly weakly developed; paraphyses simple or scarcely branched, more or less constricted at septa; asci 8-spored, rarely (1-)2-6-spored; ascospores simple, hyaline, mostly ellipsoid to almost spherical.

Conidia bacilliform to filliform, straight or slightly curved.

Chemistry: substictic acid present.

Ecology: It grows on siliceous rocks, limestone, schistose limestone and serpentine, often growing side by side with other taxa of the same genus. 


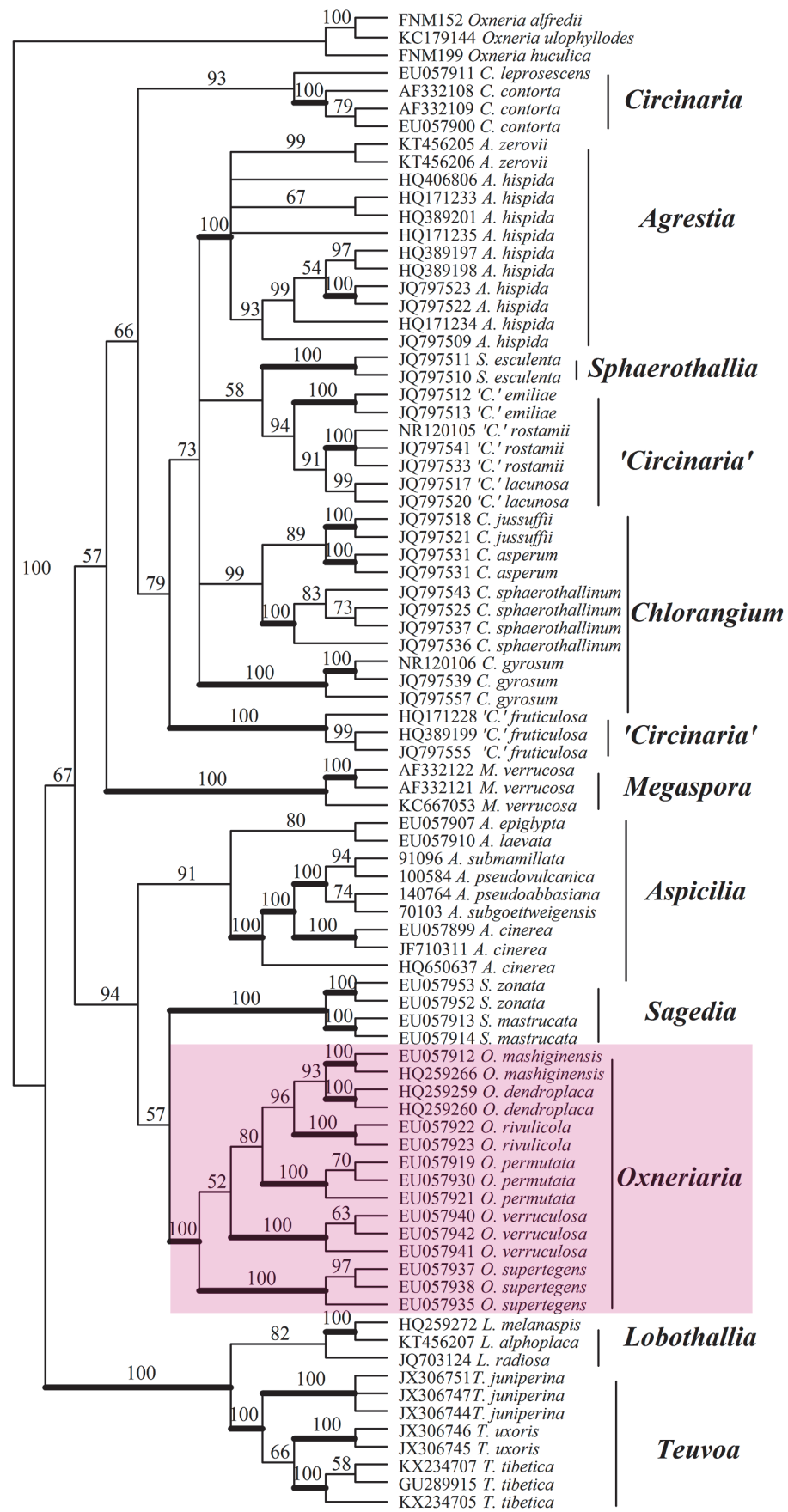

Fig. 9. Combined phylogenetic tree of the members of the Megasporaceae based on ITS and $28 \mathrm{~S}$ nLSU, and $12 \mathrm{~S} \mathrm{mtSSU}$ sequences 
Etymology: It is named after the well-known Ukrainian lichenologist Alfred Oxner (1898-1973) (Kiev, Ukraine) who provided important contribution to taxonomy of aspicilioid lichens and to biodiversity of polar lichens, i.e.: he prepared the first key to Eurasian species of the genus Aspicilia as well as for the first time provided geographic analysis of the Eurasian Arctic lichen flora based on the zonal approach, where this group of aspiciliod lichens was especially well represented. A. Oxner also prepared the first Handbook of lichens of the former Soviet Arctics (which unfortunately has been never published but this manuscript was used by several generations of Soviet lichenologists in the 20th century), as well as he has for the first time included type species of this group, i.e. Oxneriaria mashiginensis to the genus Aspicilia in his time (Oxner 1971).

Distribution and species diversity: from rare to rather widely distributed taxa in cold polar and high altitude localities of Eurasia and the northern hemisphere. So far only nine species are confirmed by molecular data, while a number of taxa are still waiting on the further revision.

Taxonomic notes: After three gene phylogeny based on nrITS, $28 \mathrm{~S}$ nrLSU and $12 \mathrm{~S} \mathrm{mtSSU}$ sequences the genus Oxneriaria for the former Aspicilia mashiginensis group found to be positioned in separate robust monophyletic branch in sister position to the Sagedia branch and positioning in distant position from the Aspicilia / Circinaria clade. Our results confirm data of previous authors that the genus Oxneriaria is positioned after nrITS analysis together with the genera Aspicilia s. str. and Sagedia in separate clade (in the clade II sensu Nordin with colleagues (Nordin et al. 2007), or the Aspicilia dendroplaca - A. supertegens group sensu Nordin with colleagues (Nordin et al. 2010) (see also Kondratyuk et al. 2016b, and Fig. 3 of this paper)). However, after combined phylogenetic data based on nrITS, $28 \mathrm{~S}$ nrLSU and $12 \mathrm{~S} \mathrm{mtSSU}$ sequences the genus Oxneriaria is positioned in the same robust monophyletic branch as Aspicilia s. str. and Sagedia (Fig. 9).

Status of the former Aspicilia mashiginensis group as separate robust monophyletic branch found to be supported by combined phylogenetic analysis based on three gene phylogeny (i.e.: nrITS, $28 \mathrm{~S}$ nrLSU and $12 \mathrm{~S} \mathrm{mtSSU}$ sequences), while after separate analysis position of this group much depends of number of taxa included into analysis. Thus from ITS data set the genus Oxneriaria is still not well supported as separate branch in case of specimens included in our analysis (it still in the Aspicilia clade, see Fig. 3), while after three gene phylogeny the genus Oxneriaria has support as separate robust monophyletic branch (Fig. 9).

The members of the genus Oxneriaria mainly distributed in cold polar and high altitude localities of Eurasia and the northern hemisphere. 


\section{New combinations}

Oxneriaria dendroplaca (H. Magn.) S. Y. Kondr. et L. Lőkös, comb. nova. - MycoBank nr.: MB 822417. - Bas.: Lecanora dendroplaca H. Magn., K. svenska Vetensk.-Akad. Handl., ser. 3, 17 (no. 5): 156 (1939). इ Aspicilia dendroplaca (H. Magn.) Oxner, in Kopachevskaya et al., Opredelitel' Lisainikov SSSR Vypusk (Handbook of the lichens of the U.S.S.R.) (Leningrad) 1: 207 (1971). Nom. inval., Art. 41.5 (Melbourne).

Oxneriaria haeyrenii (H. Magn.) S. Y. Kondr. et L. Lőkös, comb. nova. - MycoBank nr.: MB 822418. - Bas.: Lecanora haeyrenii H. Magn., K. svenska Vetensk.-Akad. Handl., ser. 3, 17 (no. 5): 43 (1939). $\equiv$ Aspicilia haeyrenii (H. Magn.) Creveld, Bibl. Lichenol. 17: 270 (1981).

Oxneriaria mashiginensis (Zahlbr.) S. Y. Kondr. et L. Lőkös, comb. nova. - MycoBank nr.: MB 822419. - Bas.: Lecanora mashiginensis Zahlbr., Rep. Sci. Res. Norw. Exped. Novaya Zemlya, 1921: 20 (1928). = Aspicilia mashiginensis (Zahlbr.) Oxner, Nov. sist. Niz. Rast. 9: 289 (1972).

Oxneriaria nikrapensis (Darb.) S. Y. Kondr. et L. Lőkös, comb. nova. MycoBank nr.: MB 822420. - Bas.: Aspicilia nikrapensis Darb., Rep. 2nd Norw. Arctic Exped. Fram., 1898-1902, 21: 12 (1909).

Oxneriaria permutata (Zahlbr.) S. Y. Kondr. et L. Lőkös, comb. nova. MycoBank nr.: MB 822421. - Bas.: Lecanora permutata Zahlbr., Cat. Lich. Univers. 5: 338 (1928). = Aspicilia permutata (Zahlbr.) Clauzade et Rondon, Revta Fac. Cien. Univ. Lisboa, Ser. 2, C 14: 17 (1966).

Oxneriaria rivulicola (H. Magn.) S. Y. Kondr. et L. Lőkös, comb. nova. MycoBank nr.: MB 822422. - Bas.: Lecanora rivulicola H. Magn., Bot. Notiser: 401 (1928). $\equiv$ Aspicilia rivulicola (H. Magn.) Räsänen, Ann. Acad. Sci. fenn., Ser. A 34 (no. 4): 73 (1931).

Oxneriaria supertegens (Arnold) S. Y. Kondr. et L. Lőkös, comb. nova. MycoBank nr.: MB 822423. - Bas.: Aspicilia supertegens Arnold, Verh. zool.-bot. Ges. Wien 27: 567 (1877).

Oxneriaria verruculosa (Kremp.) S. Y. Kondr. et L. Lőkös, comb. nova. MycoBank nr.: MB 822424. - Bas.: Aspicilia verruculosa Kremp., Denkschr. Kgl. Bayer. Bot. Ges., Abt. 2 4: 283 (1861). = Lecanora verruculosa (Kremp.) J. Steiner, Öst. Bot. Z. 65: 278 (1915).

Oxneriaria virginea (Hue) S. Y. Kondr. et L. Lőkös, comb. nova. - MycoBank nr.: MB 822425. - Bas.: Aspicilia virginea Hue, Nouv. Arch. Mus. Hist. Nat., Paris, 5 ser. 2: 70 (1912)[1910]. 三 Lecanora virginea (Hue) Zahlbr., Cat. Lich. Univers. 5: 359 (1928). 


\section{CONCLUSIONS}

The new for science species Megaspora iranica M. Haji Moniri et S. Y. Kondr. from NE Iran, similar to $M$. rimisorediata, but differing in having larger thallus, smaller soredia, thicker cortical layer of thallus, thicker hymenium, and narrower ascospores is described.

The recently described species Megaspora rimisorediata found to be much wider distributed in Eurasia (from Eastern Ukraine and Armenia to central China). Here it is for the first time recorded from Europe, from eastern Ukraine (Kharkiv oblast).

There are hitherto data on four species of the genus Megaspora (i.e. $M$. verrucosa, $M$. cretacea, $M$. rimisorediata, $M$. iranica), while some data submitted to GenBank as 'Megaspora sp.' belong to still unidentified member of the Aspicilia / Circinaria clade.

Results presented in this paper also confirm our previous data on phylogenetic analysis of aspicilioid lichens based on ITS nrDNA sequences (Kondratyuk et al. 2016b) that Aspicilia pseudoabbasiana, A. pseudovulcanica, A. subepiglypta, A. subgeographica, A. subgoettweigensis, and A. submamillata belong to the Aspicilia clade.

Status of the former Aspicilia mashiginensis group, which found to be positioned in separate robust monophyletic branch in sister position to the $S a-$ gedia branch and in distant position from the Aspicilia / Circinaria clade after three gene phylogeny based on nrITS, $28 \mathrm{~S}$ nrLSU and $12 \mathrm{~S}$ mtSSU sequences, is for the first time lifted to the generic level. Species diversity of the newly described genus Oxneriaria as well as its diagnostic characters will be clarified with accumulation of the further molecular data on the further taxa of aspicilioid lichens.

Acknowledgements - We are thankful to Dr Edit Farkas (Vácrátót, Hungary) for valuable comments on manuscript, and Dr Harrie Sipman (Berlin, Germany) for kind help with sending/providing specimens for comparative study, to Dr Yuriy G. Gamulya (Kharkiv, Ukraine) for providing data on plant communities, as well as to Dr Jae-Seoun Hur (Suncheon, Republic of Korea) for providing facilities for microscopical study and making photos, as well as for providing molecular data for Megaspora iranica. SK is thankful to Ministry of Education and Science of Ukraine (M/90-2015-285 and M/34-2016-285) and Korean Brain Pool Program (161S-4-3-1659) for financial support. 


\section{REFERENCES}

Arup, U., Søchting, U. and Frödén, P. (2013): A new taxonomy of the family Teloschistaceae. - Nord. J. Bot. 31(1): 16-83. http://dx.doi.org/10.1111/j.1756-1051.2013.00062.x

Fedorenko, N. M., Stenroos, S., Thell, A., Kärnefelt, I. and Kondratyuk, S. Y. (2009): A phylogenetic analysis of xanthorioid lichens (Teloschistaceae, Ascomycota) based on ITS and $\mathrm{mtSSU}$ sequences. - Bibl. Lichenol. 100: 49-84.

Fedorenko, N. M., Stenroos, S., Thell, A., Kärnefelt, I., Elix, J. A., Hur, J.-S. and Kondratyuk, S. Y. (2012): Molecular phylogeny of xanthorioid lichens (Teloschistaceae, Ascomycota), with notes on their morphology. - Bibl. Lichenol. 108: 45-64.

Gasparyan, A. and Sipman, H. J. M. (2013): New lichen records from Armenia. - Mycotaxon 123: 491-495.

Ivanova, N. V. and Hafellner, J. (2002): Searching for the correct placement of Megaspora by use of ITS1, 5.8S and ITS2 rDNA sequence data. - Bibl. Lichenol. 82: 123-140.

Kondratyuk, S., Jeong, M.-H., Yu, N.-H., Kärnefelt, I., Thell, A., Elix, J. A., Kim, J., Kondratyuk, A. S. and Hur, J.-S. (2013): Four new genera of teloschistoid lichens (Teloschistaceae, Ascomycota) based on molecular phylogeny. - Acta Bot. Hung. 55(3-4): 251-274. https://doi.org/10.1556/abot.55.2013.3-4.8

Kondratyuk, S. Y., Jeong, M.-H., Yu, N.-N., Kärnefelt, I., Thell, A., Elix, J. A., Kim, J., Kondratiuk, A. S. and Hur, J.-S. (2014a): A revised taxonomy for the subfamily Caloplacoideae (Teloschistaceae, Ascomycota) based on molecular phylogeny. - Acta Bot. Hung. 56(1-2): 93-123. https://doi.org/10.1556/abot.56.2014.1-2.10

Kondratyuk, S. Y., Kärnefelt, I., Thell, A., Elix, J. A., Kim, J., Jeong, M.-H., Yu, N.-H., Kondratiuk, A. S. and Hur, J.-S. (2014b): A revised taxonomy of the subfamily Xanthorioideae (Teloschistaceae, Ascomycota) based on molecular phylogeny. - Acta Bot. Hung. 56(1-2): 141-178. https://doi.org/10.1556/abot.56.2014.1-2.12

Kondratyuk, S. Y., Jeong, M.-H., Galanina, I. A., Yakovchenko, L. S., Yatsyna, A. P. and Hur, J.-S. (2014c): Molecular phylogeny of placodioid lichen-forming fungi reveal a new genus, Sedelnikovaea. - Mycotaxon 129(2): 269-282. https://doi.org/10.5248/129.269

Kondratyuk, S. Y., Gromakova, A. B., Khodosovtsev, A. Y., Kim, J. A., Kondratiuk, A. S. and Hur, J.-S. (2015): Agrestia zerovii (Megasporaceae, lichen-forming Ascomycetes), a new species from southeastern Europe proved by alternative phylogenetic analysis. - Studia bot. hung. 46(2): 69-94. https://doi.org/10.17110/studbot.2015.46.2.69

Kondratyuk, S. Y., Lőkös, L., Halda, J. P., Upreti, D. K., Mishra, G. K., Haji Moniri, M., Farkas, E., Park, J. S., Lee, B. G., Liu, D., Woo, J.-J., Jayalal, R. G. U., Oh, S.-O. and Hur, J.-S. (2016a): New and noteworthy lichen-forming and lichenicolous fungi 5. - Acta Bot. Hung. 58(3-4): 319-396. https://doi.org/10.1556/abot.58.2016.3-4.7

Kondratyuk, S. Y., Lőkös, L., Park, J.-S., Jang, S.-H., Jeong, M.-H. and Hur, J.-S. (2016b): New Aspicilia species from South Korea proved by molecular phylogeny with a key to the Eastern Asian aspicilioid lichens. - Studia bot. hung. 47(2): 227-249. https://doi. org/10.17110/studbot.2016.47.2.227

Kou, X.-R., Li, S.-X. and Ren, Q. (2013): Three new species and one new record of Lobothallia from China. - Mycotaxon 123: 241-249. https://doi.org/10.5248/123.241

Lumbsch, H. T. and Huhndorf, S. M. (2010): Myconet Volume 14. Part one. Outline of Ascomycota - 2009. Part two. Notes on Ascomycete systematics. Nos. 4751-5113. Fieldiana: Life and Earth Sciences 1: 1-64. https://doi.org/10.3158/1557.1

Miadłikowska, J., Kauff, F., Hofstetter, V., Fraker, E., Grube, M., Hafellner, J., Reeb, V., Hodkinson, B. P., Kukwa, M., Lücking, R., Hestmark, G., Otalora, M. G., Rauhut, A., Büdel, B., Scheidegger, C., Timdal, E., Stenroos, S., Brodo, I., Perlmutter, G. B., Ertz, 
D., Diederich, P., Lendemer, J. C., May, P., Schoch, C. L., Arnold, A. E., Gueidan, C., Tripp, E., Yahr, R., Robertson, C. and Lutzoni, F. (2006): New insights into classifi cation and evolution of the Lecanoromycetes (Pezizomycotina, Ascomycota) from phylogenetic analyses of three ribosomal RNA- and two protein-coding genes. - Mycologia 98(6): 1088-1103. http://dx.doi.org/10.3852/mycologia.98.6.1088

Nordin, A., Owe-Larsson, B. and Tibell, L. (2011): Two new Aspicilia species from Fennoscandia and Russia. - Lichenologist 43(1): 27-37. https://doi.org/10.1017/ s0024282910000629

Nordin, A., Savič, S. and Tibell, L. (2010): Phylogeny and taxonomy of Aspicilia and Megasporaceae. - Mycologia 102: 1339-1349. https://doi.org/10.3852/09-266

Nordin, A., Tibell, L. and Owe-Larsson, B. R. (2007): A preliminary phylogeny of Aspicilia in relation to morphological and secondary product variation. - Bibl. Lichenol. 96: 247-266.

Owe-Larsson, B., Nordin, A., Tibell, L. and Sohrabi, M. (2011): Circinaria arida spec. nova and the Aspicilia desertorum complex. - Bibl. Lichenol. 106: 235-246.

Oxner, A. N. (1971): Aspicilia Massal. - In: Kopaczevskaja, E. F., Makarevicz, M. F., Oxner, A. N. and Rassadina, K. A. (eds): Handbook of the lichens of the USSR. Vol. 1. Nauka, Leningrad, pp. 146-217. [in Russian]

Paukov, A., Nordin, A., Tibell, L., Frolov, I. and Vondrák, J. (2016): Aspicilia goettweigensis (Megasporaceae, lichenized Ascomycetes) - a poorly known and overlooked species in Europe and Russia. - Nordic J. Bot., early view, online version. https://doi. org/10.1111/njb.01222

Roux, C., Nordin, A., Tibell, L. and Sohrabi, M. (2011): Some poorly known or new Aspicilia species from Pyrenees-Orientales (France). - Bull. Soc. Linn. Provence 14: 177-227.

Schmitt, I., Yamamoto, Y. and Lumbsch, T. (2006): Phylogeny of Pertusariales (Ascomycotina): resurrection of Ochrolechiaceae and new circumscription of Megasporaceae. - J. Hattori Bot. Lab. 100: 753-764.

Schmull, M., Miadłikowska, J., Pelzer, M., Stocker-Wörgötter, E., Hofstetter, V., Fraker, E., Hodkinson, B. P., Reeb, V., Kukwa, M., Lumbsch, H. T., Kauff, F. and Lutzoni, F. (2011): Phylogenetic affiliations of members of the heterogeneous lichen-forming fungi of the genus Lecidea sensu Zahlbruckner (Lecanoromycetes, Ascomycota). Mycologia 103(5): 983-1003. https://doi.org/10.3852/10-234

Sohrabi, M., Ahti, T. and Litterski, B. (2011a): Aspicilia digitata sp. nov., a new vagrant lichen from Kyrgyzstan. - Lichenologist 43: 39-46. https://doi.org/10.1017/s0024282910000538

Sohrabi, M., Myllys, M. and Stenroos, S. (2010): Successful DNA sequencing of a 75-yearold herbarium specimen Aspicilia aschabadensis ( J. Steiner) Mereschk. - Lichenologist 42: 626-628. https://doi.org/10.1017/s0024282910000344

Sohrabi, M., Stenroos, S., Högnabba, F., Nordin, A. and Owe-Larsson, B. (2011b): Aspicilia rogeri sp. nov., (Megasporaceae) and other allied vagrant species in North America. - Bryologist 114: 178-189. https://doi.org/10.1639/0007-2745-114.1.178

Sohrabi, M., Leavitt, S. D., Rico, V. J., Halici, M. G., Shrestha, G. and Stenroos, S. (2013a): Teuvoa, a new lichen-forming fungal genus in Megasporaceae (Ascomycota: Pertusariales), including Teuvoa junipericola sp. nov. - Lichenologist 45: 347-360. https:// doi.org/10.1017/s0024282913000108

Sohrabi, M., Stenroos, S., Myllys, L., Søchting, U., Ahti, T. and Hyvönen, J. (2013b): Phylogeny and taxonomy of the 'manna lichens'. - Mycol. Progr. 12: 231-269. https://doi. org/10.1007/s11557-012-0830-1

Valadbeigi, T., Nordin, A. and Tibell, L. (2011): Megaspora rimisorediata (Pertusariales, Megasporaceae), a new sorediate species from Iran and its affinities with Aspicilia sensu lato. - Lichenologist 43(4): 285-291. https://doi.org/10.1017/s0024282911000211 
Wedin, M., Wiklund, E., Crewe, A., Döring, H., Ekman, S., Nyberg, A., Schmitt, I. and Lumbsch, H. T. (2005): Phylogenetic relationships of Lecanoromycetes (Ascomycota) as revealed by analyses of mtSSU and nLSU rDNA sequence data. - Mycol. Res. 109(2): 159-172.

Zakeri, Z., Gasparyan, A. and Aptroot, A. (2016): A new corticolous Megaspora (Megasporaceae) species from Armenia. - Willdenowia 46: 245-251. https://doi.org/10.3372/ wi.46.46205

\section{APPENDIX}

Voucher specimens and NCBI GenBank accession numbers of the nrITS, nrLSU and $\mathrm{mtSSU}$ sequences used in the phylogenetic analyses

\begin{tabular}{|c|c|c|c|c|}
\hline Taxon name & Country, voucher, reference & ITS1/ITS2 & LSU & $\mathrm{mtSSU}$ \\
\hline Agrestia hispida s. str. & Iran, Sohrabi et al. (2011b) & HQ389197 & & \\
\hline Agrestia hispida s. str. & USA, Sohrabi et al. (2011b) & HQ389198 & & \\
\hline Agrestia hispida s. str. & $\begin{array}{l}\text { Iran, Golestan, Sohrabi } 15099 \\
\text { (hb. M. Sohrabi), Sohrabi et al. } \\
(2011 a)\end{array}$ & HQ171233 & & \\
\hline Agrestia hispida s. 1. & USA, Sohrabi et al. (2011a) & HQ171234 & & \\
\hline Agrestia hispida s. str. & $\begin{array}{l}\text { Russia, Kalmyk, Sohrabi et al. } \\
(2011 a)\end{array}$ & HQ171235 & & \\
\hline Agrestia hispida s. str. & $\begin{array}{l}\text { Iran, Golestan, Sohrabi } 15099 \\
\text { (hb. M. Sohrabi), Sohrabi et al. } \\
(2013 a)\end{array}$ & JQ797509 & JQ797503 & JQ797488 \\
\hline Agrestia hispida s. str. & $\begin{array}{l}\text { Turkey, Candan } 11 \text { (ANES), } \\
\text { Nordin et al. (2010) }\end{array}$ & & HМ060760 & HM060722 \\
\hline Agrestia hispida s. str. & $\begin{array}{l}\text { Iran, (hb. M. Sohrabi), Sohrabi et } \\
\text { al. (2013a) }\end{array}$ & JQ797522 & & \\
\hline Agrestia hispida s. str. & $\begin{array}{l}\text { Iran, (hb. M. Sohrabi), Sohrabi et } \\
\text { al. (2013a) }\end{array}$ & JQ797523 & & \\
\hline Agrestia hispida s. str. & $\begin{array}{l}\text { Iran, (hb. M. Sohrabi), Sohrabi et } \\
\text { al. }(2013 a)\end{array}$ & HQ389201 & & \\
\hline Agrestia hispida s. str. & $\begin{array}{l}\text { Turkey, Candan } 11 \text { (ANES), } \\
\text { Owe-Larsson et al. (2011), } \\
\text { Sohrabi et al. (2013a as Circinaria } \\
\text { hispida s. str.) }\end{array}$ & HQ406806 & & \\
\hline Agrestia hispida & $\begin{array}{l}\text { Spain, Lumbsch, 2.06.2003 (F), } \\
\text { Schmitt et al. (2006) }\end{array}$ & & DQ780305 & DQ780273 \\
\hline Agrestia zerovii & $\begin{array}{l}\text { SK A12, Ukraine, Kharkiv oblast, } \\
\text { Dvorychansky district, "Korob- } \\
\text { chyno" zakaznik, 19.06.2013, M. } \\
\text { Kryvokhyzhaya (KW-L), Kond- } \\
\text { ratyuk et al. (2015 as Circinaria) }\end{array}$ & KT456205 & KT456208 & \\
\hline
\end{tabular}




\begin{tabular}{|c|c|c|c|c|}
\hline Taxon name & Country, voucher, reference & ITS1/ITS2 & LSU & $\mathrm{mtSSU}$ \\
\hline Agrestia zerovii & $\begin{array}{l}\text { SK A12, Ukraine, Kharkiv oblast, } \\
\text { Dvorychansky district, "Korob- } \\
\text { chyno" zakaznik, 19.06.2013, M. } \\
\text { Kryvokhyzhaya (KW-L), Kond- } \\
\text { ratyuk et al. (2014a as Circinaria } \\
\text { hispida) }\end{array}$ & & & KP059052 \\
\hline Agrestia zerovii & $\begin{array}{l}\text { SK A15, Ukraine, Kharkiv oblast, } \\
\text { Dvorychansky district, "Korob- } \\
\text { chyno" zakaznik, } 19.06 .2013, \mathrm{M} \text {. } \\
\text { Kryvokhyzhaya } 2 \text { (KW-L), Kond- } \\
\text { ratyuk et al. (2015 as Circinaria) }\end{array}$ & KT456206 & KT456209 & \\
\hline Agrestia zerovii & $\begin{array}{l}\text { SK A15, Ukraine, Kharkiv oblast, } \\
\text { Dvorychansky district, "Korob- } \\
\text { chyno" zakaznik, 19.06.2013, M. } \\
\text { Kryvokhyzhaya } 2 \text { (KW-L), Kond- } \\
\text { ratyuk et al. (2014a as Circinaria } \\
\text { hispida) }\end{array}$ & & & КР059053 \\
\hline Aspicilia blastidiata & Paukov et al. (2016) & KX129963 & & \\
\hline Aspicilia caesiocinerea & $\begin{array}{l}\text { AFTOL-ID 653, Miadłikowska et } \\
\text { al. (2006) }\end{array}$ & & & DQ986892 \\
\hline Aspicilia cinerea & $\begin{array}{l}\text { AFTOL-ID 647, Schmull et al. } \\
\text { (2011) }\end{array}$ & HQ650637 & & \\
\hline Aspicilia cinerea & $\begin{array}{l}\text { AFTOL-ID 647, Miadtikowska et } \\
\text { al. (2006) }\end{array}$ & & DQ986779 & DQ986890 \\
\hline Aspicilia cinerea & $\begin{array}{l}\text { Sweden, Dalarna, Hermansson } \\
13275 \text { (UPS), Nordin et al. (2007) }\end{array}$ & EU057899 & HM060733 & HM060695 \\
\hline Aspicilia cinerea & France, Roux et al. (2011) & JF710311 & & \\
\hline Aspicilia cinerea & $\begin{array}{l}\text { South Korea, Kondratyuk et al. } \\
(2016 b)\end{array}$ & KY249596 & & \\
\hline Aspicilia epiglypta & $\begin{array}{l}\text { Sweden, Nordin } 6303 \text { (UPS), } \\
\text { Nordin et al. (2007) }\end{array}$ & EU057907 & & \\
\hline Aspicilia epiglypta & $\begin{array}{l}\text { Sweden, Nordin } 6303 \text { (UPS), } \\
\text { Nordin et al. (2010) }\end{array}$ & & HМ060756 & HM060718 \\
\hline Aspicilia epiglypta & $\begin{array}{l}\text { Sweden, Nordin } 6303 \text { (UPS), } \\
\text { Nordin et al. (2011) }\end{array}$ & HQ259261 & & \\
\hline Aspicilia goettweigensis & Paukov et al. (2016) & KX159289 & & \\
\hline Aspicilia goettweigensis & Paukov et al. (2016) & KX159292 & & \\
\hline Aspicilia indissimilis & Nordin et al. (2007) & EU057909 & & \\
\hline Aspicilia laevata & $\begin{array}{l}\text { Sweden, Tibell } 23659 \text { (UPS), } \\
\text { Nordin et al. (2007) }\end{array}$ & EU057910 & & \\
\hline Aspicilia laevata & $\begin{array}{l}\text { Sweden, Tibell } 23659 \text { (UPS), } \\
\text { Nordin et al. (2010) }\end{array}$ & & HМ060730 & HM060692 \\
\hline $\begin{array}{l}\text { Aspicilia pseudoab- } \\
\text { bassiana }\end{array}$ & $\begin{array}{l}\text { South Korea, 140764, Kondra- } \\
\text { tyuk et al. }(2016 b)\end{array}$ & KY249599 & & \\
\hline
\end{tabular}




\begin{tabular}{|c|c|c|c|c|}
\hline Taxon name & Country, voucher, reference & ITS1/ITS2 & LSU & $\mathrm{mtSSU}$ \\
\hline $\begin{array}{l}\text { Aspicilia pseudoab- } \\
\text { bassiana }\end{array}$ & $\begin{array}{l}\text { South Korea, 100188, Kondra- } \\
\text { tyuk et al. }(2016 b)\end{array}$ & KY249600 & & \\
\hline $\begin{array}{l}\text { Aspicilia pseudovul- } \\
\text { canica }\end{array}$ & $\begin{array}{l}\text { South Korea, } 090722, \text { Kondra- } \\
\text { tyuk et al. }(2016 b)\end{array}$ & KY249602 & & \\
\hline $\begin{array}{l}\text { Aspicilia pseudovul- } \\
\text { canica }\end{array}$ & $\begin{array}{l}\text { South Korea, 100584, Kondra- } \\
\text { tyuk et al. }(2016 b)\end{array}$ & KY249601 & & \\
\hline Aspicilia subepiglypta & $\begin{array}{l}\text { South Korea, } 100438, \text { Kondra- } \\
\text { tyuk et al. }(2016 b)\end{array}$ & KY249606 & & \\
\hline $\begin{array}{l}\text { Aspicilia subgeo- } \\
\text { graphica }\end{array}$ & $\begin{array}{l}\text { South Korea, 130359, Kondra- } \\
\text { tyuk et al. }(2016 b)\end{array}$ & KY249611 & & \\
\hline $\begin{array}{l}\text { Aspicilia subgeo- } \\
\text { graphica }\end{array}$ & $\begin{array}{l}\text { South Korea, } 120356, \text { Kondra- } \\
\text { tyuk et al. }(2016 b)\end{array}$ & KY249610 & & \\
\hline $\begin{array}{l}\text { Aspicilia subgoettwei- } \\
\text { gensis }\end{array}$ & $\begin{array}{l}\text { South Korea, 120188, Kondra- } \\
\text { tyuk et al. }(2016 b)\end{array}$ & KY249613 & & \\
\hline $\begin{array}{l}\text { Aspicilia subgoettwei- } \\
\text { gensis }\end{array}$ & $\begin{array}{l}\text { South Korea, 130234, Kondra- } \\
\text { tyuk et al. }(2016 b)\end{array}$ & KY249614 & & \\
\hline Aspicilia subdepresa & France, Roux et al. (2011) & JF703123 & & \\
\hline Aspicilia submamillata & $\begin{array}{l}\text { South Korea, 090631, Kondra- } \\
\text { tyuk et al. }(2016 b)\end{array}$ & KY249618 & & \\
\hline Aspicilia submamillata & $\begin{array}{l}\text { South Korea, } 091073, \text { Kondra- } \\
\text { tyuk et al. }(2016 b)\end{array}$ & KY249619 & & \\
\hline Chlorangium alpicola & Kyrgyzstan, Sohrabi et al. (2013a) & JQ797556 & & \\
\hline Chlorangium alpicola & Kyrgyzstan, Sohrabi et al. (2013a) & JQ797552 & & \\
\hline Chlorangium alpicola & Kyrgyzstan, Sohrabi et al. (2013a) & JQ797524 & & \\
\hline Chlorangium alpicola & Kyrgyzstan, Sohrabi et al. (2013a) & JQ797554 & & \\
\hline $\begin{array}{l}\text { Chlorangium } \\
\text { aschabadense }\end{array}$ & $\begin{array}{l}\text { Turkmenistan, Sohrabi et al. } \\
(2013 a)\end{array}$ & JQ797519 & & \\
\hline $\begin{array}{l}\text { Chlorangium } \\
\text { aschabadense }\end{array}$ & $\begin{array}{l}\text { Turkmenistan, Sohrabi et al. } \\
\text { (2010) }\end{array}$ & GU289916 & & \\
\hline $\begin{array}{l}\text { Chlorangium cf. } \\
\text { asperum }\end{array}$ & $\begin{array}{l}\text { Russia, Astrakhan region, } \\
\text { Sohrabi et al. (2013a) }\end{array}$ & JQ797531 & & \\
\hline $\begin{array}{l}\text { Chlorangium } \mathrm{cf} . \\
\text { asperum }\end{array}$ & Aras et al. (unpubl.) & & & DQ401569 \\
\hline Chlorangium gyrosum & Spain, Sohrabi et al. (unpubl.) & JX306734 & & \\
\hline Chlorangium gyrosum & Iran, Sohrabi et al. (2013a) & NR_120106 & & \\
\hline Chlorangium gyrosum & $\begin{array}{l}\text { Iran, East Azerbaijan, Sohrabi } \\
10085 \text { (hb. M. Sohrabi), Sohrabi } \\
\text { et al. (2013a) }\end{array}$ & JQ797540 & JQ797504 & \\
\hline Chlorangium gyrosum & Iran, Sohrabi et al. (2013a) & JQ797539 & & \\
\hline Chlorangium gyrosum & Spain, Sohrabi et al. (2013a) & JQ797557 & & \\
\hline
\end{tabular}




\begin{tabular}{|c|c|c|c|c|}
\hline Taxon name & Country, voucher, reference & ITS1/ITS2 & LSU & $\mathrm{mtSSU}$ \\
\hline Chlorangium gyrosum & $\begin{array}{l}\text { Iran, East Azerbaijan, Sohrabi } \\
\text { 10401A (hb. M. Sohrabi), Sohrabi } \\
\text { et al. (2013a) }\end{array}$ & JQ797528 & & JQ797487 \\
\hline Chlorangium jussufii & Morocco, Sohrabi et al. (2013a) & JQ797521 & & \\
\hline Chlorangium jussufii & $\begin{array}{l}\text { Algeria, Esnault } 2033 \text { (GZU), } \\
\text { Sohrabi et al. (2013a) }\end{array}$ & JQ797518 & JQ797495 & JQ797489 \\
\hline $\begin{array}{l}\text { Chlorangium } \\
\text { sphaerothallinum }\end{array}$ & $\begin{array}{l}\text { Iran, Semnan, Sohrabi } 9369 \text { (hb. } \\
\text { M. Sohrabi), Sohrabi et al. (2013a) }\end{array}$ & JQ797545 & JQ797508 & JQ797476 \\
\hline $\begin{array}{l}\text { Chlorangium } \\
\text { sphaerothallinum }\end{array}$ & Iran, Sohrabi et al. (2013a) & JQ797537 & & \\
\hline $\begin{array}{l}\text { Chlorangium } \\
\text { sphaerothallinum }\end{array}$ & Iran, Sohrabi et al. (2013a) & JQ797536 & & \\
\hline $\begin{array}{l}\text { Chlorangium } \\
\text { sphaerothallinum }\end{array}$ & Iran, Sohrabi et al. (2013a) & JQ797543 & & \\
\hline $\begin{array}{l}\text { Chlorangium } \\
\text { sphaerothallinum }\end{array}$ & Armenia, Sohrabi et al. (2013a) & JQ797525 & & \\
\hline Circinaria affinis & $\begin{array}{l}\text { Russia: Astrakhan Region, } \\
\text { Kulakov 1408B (M), Sohrabi et } \\
\text { al. }(2011 b)\end{array}$ & HQ389196 & & \\
\hline Circinaria affinis & $\begin{array}{l}\text { Russia: Astrakhan Region, } \\
\text { Kulakov 1408B (M), Sohrabi et } \\
\text { al. }(2013 a)\end{array}$ & & JQ797502 & JQ797492 \\
\hline Circinaria caesiocinerea & Sweden, Nordin et al. (2007) & EU057897 & & \\
\hline Circinaria caesiocinerea & Schmitt et al. (2006) & & DQ780303 & DQ780271 \\
\hline Circinaria caesiocinerea & $\begin{array}{l}\text { United Kingdom: Wales, Orange } \\
\text { (unpubl.) }\end{array}$ & FJ532372 & & \\
\hline Circinaria calcarea & $\begin{array}{l}\text { Sweden, Öland, Nordin } 5888 \\
\text { (UPS), Nordin et al. (2007) }\end{array}$ & EU057898 & & \\
\hline Circinaria calcarea & $\begin{array}{l}\text { Sweden, Öland, Nordin } 5888 \\
\text { (UPS), Nordin et al. (2010) }\end{array}$ & & HМ060743 & HM060705 \\
\hline Circinaria calcarea & $\begin{array}{l}\text { Sweden, Owe-Larsson et al. } \\
\text { (2011) }\end{array}$ & HQ406804 & & \\
\hline Circinaria calcarea & $\begin{array}{l}\text { Sweden, Wedin } 6500 \text { (UPS), } \\
\text { Wedin et al. (2005) }\end{array}$ & & & AY853310 \\
\hline Circinaria calcarea & $\begin{array}{l}\text { Austria(?), Wilfling (GZU), } \\
\text { Ivanova and Hafellner (2002) }\end{array}$ & AF332108 & & \\
\hline Circinaria calcarea & $\begin{array}{l}\text { AFTOL-ID 1358, Miadłikowska } \\
\text { et al. (2006) }\end{array}$ & & & DQ986876 \\
\hline Circinaria cerebroides & $\begin{array}{l}\text { Kyrgyzstan, Innerer Tian-Shan, } \\
\text { Ringel 5138(H), Sohrabi et al. } \\
(2013 a)\end{array}$ & JQ797534 & JQ797506 & JQ797484 \\
\hline Circinaria contorta & Sweden, Nordin et al. (2007) & EU057900 & & \\
\hline
\end{tabular}




\begin{tabular}{|c|c|c|c|c|}
\hline Taxon name & Country, voucher, reference & ITS1/ITS2 & LSU & mtSSU \\
\hline Circinaria contorta & $\begin{array}{l}\text { Austria (GZU), Ivanova and } \\
\text { Hafellner (2002) }\end{array}$ & AF332108 & & \\
\hline Circinaria contorta & $\begin{array}{l}\text { Austria (GZU), Ivanova and } \\
\text { Hafellner (2002) }\end{array}$ & AF332109 & & \\
\hline Circinaria desertorum & USA, Nordin et al. (2007) & EU057905 & & \\
\hline Circinaria desertorum & Russia, Owe-Larsson et al. (2011) & HQ406802 & & \\
\hline Circinaria desertorum & Russia, Nordin et al. (2010) & & & HM060689 \\
\hline Circinaria digitata & Kyrgyzstan, Sohrabi et al. (2011a) & HQ171230 & & \\
\hline Circinaria digitata & Kyrgyzstan, Sohrabi et al. (2011a) & HQ171236 & & \\
\hline Circinaria elmorei & Nordin et al. (2010) & HQ406802 & HM060727 & HM060689 \\
\hline Circinaria cf. elmorei & $\begin{array}{l}\text { Ukraine: Crimea, Sohrabi et al. } \\
(2013 a)\end{array}$ & JQ797551 & & \\
\hline Circinaria cf. elmorei & Iran, Sohrabi et al. (2013a) & JQ797542 & & \\
\hline Circinaria cf. elmorei & Iran, Sohrabi et al. (2013a) & JQ797526 & & \\
\hline Circinaria cf. elmorei & Iran, Sohrabi et al. (2013a) & JQ797558 & & \\
\hline Circinaria gibbosa & $\begin{array}{l}\text { Sweden, Uppland, Nordin } 5878 \\
\text { (UPS), Nordin et al. (2007) }\end{array}$ & EU05790 & & \\
\hline Circinaria gibbosa & $\begin{array}{l}\text { Sweden, Uppland, Nordin } 5878 \\
\text { (UPS), Nordin et al. (2010) }\end{array}$ & & HM060740 & HM060702 \\
\hline Circinaria leprosescens & $\begin{array}{l}\text { Sweden, Uppland, Nordin } 5906 \\
\text { (UPS), Nordin et al. (2007) }\end{array}$ & EU05791 & & \\
\hline Circinaria leprosescens & $\begin{array}{l}\text { Sweden, Uppland, Nordin } 5906 \\
\text { (UPS), Nordin et al. (2010) }\end{array}$ & & HM060749 & HM060711 \\
\hline Circinaria rogeri & USA, Sohrabi et al. (2011a) & HQ171231 & & \\
\hline Circinaria rogeri & USA, Sohrabi et al. (2011a) & HQ171232 & & \\
\hline 'Circinaria' emiliae & $\begin{array}{l}\text { Kazakhstan, Atyrau, Kulakov } \\
3702 \text { (UPS), Sohrabi et al. (2013a) }\end{array}$ & JQ797512 & & \\
\hline 'Circinaria' emiliae & $\begin{array}{l}\text { Kazakhstan, Atyrau, Kulakov } \\
3702 \text { (UPS), Nordin et al. (2010) }\end{array}$ & & HM060728 & HM060690 \\
\hline 'Circinaria' emiliae & $\begin{array}{l}\text { Kazakhstan, Atyrau, Kula- } \\
\text { kov 3702B (UPS), Sohrabi et al. } \\
(2013 a)\end{array}$ & JQ797513 & & \\
\hline 'Circinaria' emiliae & $\begin{array}{l}\text { Kazakhstan, Atyrau, Kulakov } \\
3798 \text { (UPS), Nordin et al. (2010) }\end{array}$ & & HM060729 & HM060691 \\
\hline 'Circinaria' fruticulosa & $\begin{array}{l}\text { Ukraine: Crimea, Sohrabi et al. } \\
(2013 a)\end{array}$ & JQ797555 & & \\
\hline 'Circinaria' fruticulosa & Turkey, Sohrabi et al. (2013a) & JQ797535 & & \\
\hline 'Circinaria' fruticulosa & $\begin{array}{l}\text { Kazakhstan, Tarbagatai, Lange } \\
5186(\mathrm{H}), \text { Sohrabi et al. }(2013 b)\end{array}$ & HQ171228 & JQ797505 & JQ797486 \\
\hline 'Circinaria' lacunosa & Kazakhstan, Sohrabi et al. (2013a) & JQ797520 & & \\
\hline
\end{tabular}




\begin{tabular}{|c|c|c|c|c|}
\hline Taxon name & Country, voucher, reference & ITS1/ITS2 & LSU & $\mathrm{mtSSU}$ \\
\hline 'Circinaria' lacunosa & $\begin{array}{l}\text { China, Xinjiang, Abbas } 940003 \\
\text { (H), Sohrabi et al. (2013a) }\end{array}$ & JQ797517 & JQ797494 & JQ797490 \\
\hline 'Circinaria' rostamii & $\begin{array}{l}\text { Iran, East Azerbaijan, Sohrabi } \\
10212 \text { (IRAN), Sohrabi et al. } \\
\text { (2013a) }\end{array}$ & JQ797538 & JQ797507 & JQ797491 \\
\hline 'Circinaria' rostamii & Iran, Sohrabi et al. (2013a) & JQ797533 & & \\
\hline 'Circinaria' rostamii & Iran, Sohrabi et al. (2013a) & JQ797541 & & \\
\hline Lobothallia alphoplaca & USA, Sohrabi et al. (unpubl.) & JX306737 & & \\
\hline Lobothallia alphoplaca & USA, Sohrabi et al. (unpubl.) & JX306738 & & \\
\hline Lobothallia alphoplaca & USA, Sohrabi et al. (unpubl.) & JX306739 & & \\
\hline Lobothallia alphoplaca & China, Kou et al. (2013) & JX476025 & & \\
\hline Lobothallia alphoplaca & $\begin{array}{l}\text { SK A20, Ukraine, Kondratyuk et } \\
\text { al. (2015) }\end{array}$ & KT456207 & KT456210 & KT456211 \\
\hline Lobothallia melanaspis & Norway, Valadbeigi et al. (2011) & JF825524 & & \\
\hline Lobothallia melanaspis & $\begin{array}{l}\text { Sweden, Jämtland, Nordin } 6622 \\
\text { (UPS), Nordin et al. (2011) }\end{array}$ & HQ259272 & & \\
\hline Lobothallia melanaspis & $\begin{array}{l}\text { Sweden, Jämtland, Nordin } 6622 \\
\text { (UPS), Nordin et al. (2010) }\end{array}$ & & HM060726 & HM060688 \\
\hline Lobothallia preradiosa & $\begin{array}{l}\text { China, Ismayil and Abbas } \\
\text { (unpubl.) }\end{array}$ & KT180161 & & \\
\hline Lobothallia radiosa & Sweden, Roux et al. (2011) & JF703124 & & \\
\hline Lobothallia radiosa & $\begin{array}{l}\text { Switzerland, Lumbsch (F), } \\
\text { Schmitt et al. (2006) }\end{array}$ & & DQ780306 & DQ780274 \\
\hline Lobothallia recedens & $\begin{array}{l}\text { Sweden, Dalarna, Nordin } 6582 \\
\text { (UPS), Nordin et al. (2010) }\end{array}$ & & HM060762 & HМ060724 \\
\hline Megaspora cretacea & Zakeri et al. (2016) & KX253974 & & \\
\hline Megaspora cretacea & Zakeri et al. (2016) & KX253975 & & \\
\hline Megaspora iranica & $\begin{array}{l}\text { Iran, Haji Moniri M. 13.12.2013 } \\
\text { (KW-L, SK D67), this paper }\end{array}$ & 150318 & & \\
\hline Megaspora iranica & $\begin{array}{l}\text { Iran, Haji Moniri M. } 13.12 .2013 \\
\text { (BP, SK D69), this paper }\end{array}$ & 141053 & & \\
\hline Megaspora rimisorediata & Iran, Valadbeigi et al. (2011) & JF825525 & & \\
\hline Megaspora rimisorediata & China, Ismayil (unpubl.) & KT443787 & & \\
\hline Megaspora rimisorediata & China, Ismayil (unpubl.) & KT443788 & & \\
\hline Megaspora rimisorediata & China, Ismayil (unpubl.) & KT443789 & & \\
\hline Megaspora rimisorediata & China, Ismayil (unpubl.) & KT443790 & & \\
\hline Megaspora verrucosa & $\begin{array}{l}\text { Austria? /1996, Trinkaus (GZU), } \\
\text { Ivanova and Hafellner (2002) }\end{array}$ & AF332121 & & \\
\hline Megaspora verrucosa & $\begin{array}{l}\text { Austria(?), Hafellner } 48544 \text { and } \\
\text { Ivanova (GZU), Ivanova and } \\
\text { Hafellner (2002) }\end{array}$ & AF332122 & & \\
\hline
\end{tabular}




\begin{tabular}{|c|c|c|c|c|}
\hline Taxon name & Country, voucher, reference & ITS1/ITS2 & LSU & $\mathrm{mtSSU}$ \\
\hline Megaspora verrucosa & USA, Sohrabi et al. (2013a) & KC667053 & & \\
\hline Megaspora verrucosa & $\begin{array}{l}\text { Sweden, Jämtland, Nordin } 6495 \\
\text { (UPS), Nordin et al. (2010) }\end{array}$ & & HM060725 & HM060687 \\
\hline Megaspora verrucosa & $\begin{array}{l}\text { Iran, East Azerbaijan, Sipman } \\
55434 \text { (B), Sohrabi } \text { et al. (2013a) }\end{array}$ & & JQ797498 & JQ797483 \\
\hline Megaspora verrucosa & $\begin{array}{l}\text { Turkey, Prov. Çorum, Kinalioğlu } \\
1679 \text { (B), Sohrabi et al. (2013a) }\end{array}$ & & JQ797497 & JQ797482 \\
\hline Megaspora verrucosa & China, Xinjiang, XJU 200753 & KT443786 & & \\
\hline Megaspora verrucosa & China, Xinjiang, XJU 200724 & KT443785 & & \\
\hline Oxneria alfredi & FNM 152, Fedorenko et al. (2009) & EU681344 & & EU680932 \\
\hline Oxneria huculica & FNM 199, Fedorenko et al. (2009) & EU681346 & & EU680931 \\
\hline Oxneria huculica & Arup et al. (2013) & & KC179279 & \\
\hline Oxneria ulophyllodes & FNM 198, Fedorenko et al. (2009) & EU681342 & & EU680930 \\
\hline Oxneria ulophyllodes & Arup et al. (2013) & & KC179283 & \\
\hline Oxneriaria dendroplaca & Nordin 5952, Nordin et al. (2011) & HQ259259 & & \\
\hline Oxneriaria dendroplaca & T 538, Nordin et al. (2010) & & HM060706 & \\
\hline Oxneriaria dendroplaca & T747 5952, Nordin et al. (2010) & & HM060720 & HM060706 \\
\hline Oxneriaria dendroplaca & Nordin 6366, Nordin et al. (2011) & HQ259260 & & \\
\hline $\begin{array}{l}\text { Oxneriaria mashigi- } \\
\text { nensis }\end{array}$ & Nordin et al. (2007) & EU057912 & & \\
\hline $\begin{array}{l}\text { Oxneriaria mashigi- } \\
\text { nensis }\end{array}$ & T455, Nordin et al. (2010) & & HM060732 & HM060694 \\
\hline $\begin{array}{l}\text { Oxneriaria mashigi- } \\
\text { nensis }\end{array}$ & T23557, Nordin et al. (2011) & HQ259266 & & \\
\hline Oxneriaria permutata & Nordin et al. (2007) & EU057919 & & \\
\hline Oxneriaria permutata & T550, Nordin et al. (2010) & & HM060747 & HM060709 \\
\hline Oxneriaria permutata & Nordin et al. (2007) & EU057921 & & \\
\hline Oxneriaria permutata & Nordin et al. (2007) & EU057930 & & \\
\hline Oxneriaria rivulicola & Nordin et al. (2007) & EU057922 & & \\
\hline Oxneriaria rivulicola & T668, Nordin et al. (2010) & & HM060715 & \\
\hline Oxneriaria rivulicola & Nordin et al. (2007) & EU057923 & & \\
\hline Oxneriaria supertegens & Nordin et al. (2007) & EU057935 & & \\
\hline Oxneriaria supertegens & T610, Nordin et al. (2010) & & HM060713 & \\
\hline Oxneriaria supertegens & T508, Nordin et al. (2010) & & HМ060704 & \\
\hline Oxneriaria supertegens & Nordin et al. (2007) & EU057937 & & \\
\hline Oxneriaria supertegens & Nordin et al. (2007) & EU057938 & & \\
\hline Oxneriaria verruculosa & T507, Nordin et al. (2007) & EU057940 & & \\
\hline Oxneriaria verruculosa & T507, Nordin et al. (2007) & & HM060741 & HМ060703 \\
\hline
\end{tabular}




\begin{tabular}{|c|c|c|c|c|}
\hline Taxon name & Country, voucher, reference & ITS1/ITS2 & LSU & $\mathrm{mtSSU}$ \\
\hline Oxneriaria verruculosa & T507, Nordin et al. (2007) & EU057941 & & \\
\hline Oxneriaria verruculosa & T507, Nordin et al. (2007) & EU057942 & & \\
\hline Oxneriaria virginea & Nordin et al. (2011) & HQ259270 & & \\
\hline Oxneriaria virginea & Nordin et al. (2011) & HQ259271 & & \\
\hline Sagedia mastrucata & $\begin{array}{l}\text { Sweden, Lycksele Lappmark, } \\
\text { Nordin } 5481 \text { (UPS), Nordin et al. } \\
\text { (2007) }\end{array}$ & EU057914 & & \\
\hline Sagedia mastrucata & $\begin{array}{l}\text { Sweden, Lycksele Lappmark, } \\
\text { Nordin } 5481 \text { (UPS), Nordin et al. } \\
(2010)\end{array}$ & & HM060737 & M060699 \\
\hline Sagedia mastrucata & $\begin{array}{l}\text { Norway, Troms, Nordin } 5708 \\
\text { (UPS), Nordin et al. (2007) }\end{array}$ & EU057913 & & \\
\hline Sagedia mastrucata & $\begin{array}{l}\text { Norway, Troms, Nordin } 5708 \\
\text { (UPS), Nordin et al. (2010) }\end{array}$ & & HМ060736 & HM060698 \\
\hline Sagedia mastrucata & Nordin et al. (2007) & EU057915 & & \\
\hline Sagedia mastrucata & Nordin et al. (2007) & EU057916 & & \\
\hline Sagedia mastrucata & Nordin et al. (2007) & EU057917 & & \\
\hline Sagedia nunatakensis & Jiri (unpubl.) & KT630250 & & \\
\hline Sagedia simoensis & Nordin et al. (2007) & EU057926 & & \\
\hline Sagedia simoensis & Nordin et al. (2010) & & HМ060739 & HM060701 \\
\hline Sagedia simoensis & Nordin et al. (2007) & EU057929 & & \\
\hline Sagedia simoensis & Ivanova and Hafellner (2002) & AF332113 & & \\
\hline Sagedia simoensis & Ivanova and Hafellner (2002) & AF332115 & & \\
\hline Sagedia simoensis & Jiri (unpubl.) & KT630249 & & KT630251 \\
\hline Sagedia zonata & Nordin et al. (2007) & EU057949 & & \\
\hline Sagedia zonata & $\begin{array}{l}\text { Sweden, Nordin } 6006 \text { (UPS), } \\
\text { Nordin et al. (2007) }\end{array}$ & EU057951 & & \\
\hline Sagedia zonata & $\begin{array}{l}\text { Sweden, Nordin } 5949 \text { (UPS), } \\
\text { Nordin et al. (2007) }\end{array}$ & EU057953 & & \\
\hline Sagedia zonata & $\begin{array}{l}\text { Norway, Troms, Owe-Larsson } \\
8942 \text { (UPS), Nordin et al. (2010) }\end{array}$ & & HМ060738 & HM060700 \\
\hline Sphaerothallia esculenta & $\begin{array}{l}\text { Russia, Astrakhan region, } \\
\text { Sohrabi et al. (2013a) }\end{array}$ & JQ797511 & & \\
\hline Sphaerothallia esculenta & $\begin{array}{l}\text { Russia, Astrakhan Region, Owe- } \\
\text { Larsson } 9796 \text { (UPS), Sohrabi et } \\
\text { al. }(2013 a)\end{array}$ & & JQ797493 & JQ797485 \\
\hline Sphaerothallia esculenta & Sohrabi et al. (2013a) & JQ797510 & & \\
\hline Teuvoa juniperina & 742, Sohrabi et al. (2013a) & JX306747 & JX306754 & JX306758 \\
\hline Teuvoa juniperina & 765, Sohrabi et al. (2013a) & JX306745 & KC667058 & JX306757 \\
\hline Teuvoa juniperina & 766, Sohrabi et al. (2013a) & JX306741 & JX306760 & \\
\hline
\end{tabular}




\begin{tabular}{lllll} 
Taxon name & Country, voucher, reference & ITS1/ITS2 & LSU & mtSSU \\
\hline Teuvoa juniperina & 766, Sohrabi et al. $(2013 a)$ & JX306746 & KC667057 & \\
Teuvoa juniperina & 767, Sohrabi et al. $(2013 a)$ & JX306751 & JX306755 & JX306761 \\
Teuvoa juniperina & 843, Sohrabi et al. (2013a) & JX306748 & JX306762 & \\
Teuvoa juniperina & 850, Sohrabi et al. (2013a) & JX306777 & JX306756 & \\
Teuvoa tibetica & Sohrabi et al. (2013a) & GU289915 & & \\
Teuvoa tibetica & Zhang et al. (2016) (unpubl.) & KX234705 & & \\
Teuvoa tibetica & Zhang et al. (2016) (unpubl.) & KX234707 & & \\
& & & & \\
\end{tabular}

